\title{
A New Era in Metis Constitutional Rights: THE IMPORTANCE OF POWLEY AND BLAIS
}

\author{
CATHERINE BELl AND Clayton LEONARD*
}

\section{INTRODUCTION}

On 22 October 1993 Steve Powley and his son, both members of a Metis community near Sault Ste. Marie, were charged with hunting a moose without a licence and with knowingly possessing game hunted in contravention of Ontario's Game and Fish Act.' The Powleys were acquitted at trial and at every subsequent appeal, ${ }^{2}$ up to and including the Supreme Court of Canada. Ruling for the first time on the issue of Metis rights under s. 35 of the Constitution Act, $1982,{ }^{3}$ the Supreme Court recognized that the Powleys, as Metis, had a constitutionally protected Metis Aboriginal right to hunt for food. ${ }^{4}$ However, the decision has far more importance beyond the recognition of subsistence rights of the Metis in and around Sault Ste. Marie. The unanimous decision of the Court suggests that provinces which ignore the existence of Metis hunting rights do not have a valid legislative objective to infringe this right, or which fail to consult with affected Metis rights holders on issues of accommodation are in breach of the Canadian constitution.

When considered with the decision of the Supreme Court of Canada in R. v. Blais, ${ }^{5}$ released on the same day, Powley also raises questions about provincial jurisdiction to regulate in an area which, if Metis peoples or their Aboriginal rights fall within s. 91(24) of the Constitution Act, $1867,{ }^{6}$ may be of core federal jurisdiction. Acknowledging for the first time that Metis are a distinct Aboriginal people with rights analogous to First Nation and Inuit peoples, the Supreme Court elaborates a new set of legal principles specific to the assertion of Metis Aboriginal rights based in historic customs, traditions, and practices of distinctive Metis communities. Building on the framework for analysis developed in the lower courts, the Supreme Court modifies precedent on site-specific Aboriginal harvesting rights to accommodate the unique historical circumstance of the Metis in Sault Ste. Marie. The Court also pronounces on fundamental questions, such as the historical foundations of Metis rights, identification of historic and contemporary rights-bearing Metis communities,

- Catherine Bell, Professor of Law, University of Alberta and Clayton Leonard, student-at-law. The authors gratefully acknowledge the helpful comments provided by Joseph Magnet on jurisdictional issues raised in this paper.

R.S.O. 1990, c. G-1.

R. v. Powley, [2003] 2 S.C.R. 207, 4 C.N.L.R. 321, aff'g (2001), 53 O.R. (3d) 35, [2001] 2 C.N.L.R. 291 (C.A.), aff'g (2000), 47 O.R. (3d) 30, [2000] 2 C.N.I.R. 233 (Sup. Ct. J.), aff'g [1999] I C.N.I.R. 153, [1998] O.J. No. 5310 (Prov. Ct. Div.) (QL) [Pow/(') cited to C.N.L.R.].

3 Being schedule B to the Canada Act 1982 (U.K.), 1982, c. 11, ss. 35(1)-(2) read as follows:

35 (1) The existing aboriginal and treaty rights of the aboriginal peoples of Canada are hereby recognized and affirmed.

35(2) In this Act, "aboriginal peoples of Canada" includes the Indian. Inuit and Metis peoples. Powley, supra note 2.

R. v. Blais, [2003] 2 S.C.R. 236, 4 C.N.L.R. 321, aft'g (2001), 156 Man. R. (2d) 53, [2001] 3 C.N.I.R. 187 (Man. C.A.), aft'g (1998), 130 Man. R. (2d) 114, [1998] 4 C.N.L.R. 103 (Man. Q.B.), aft'g|1997|

3 C.N.L.R. 109, [1996] M.J. No. 319 (Man. Prov. Ct. Div.) (QL) [Blais cited to C.N.L.R.].

( (U.K.), $30 \& 31$ Vict., c. 3, R.S.C. 1985, App. II, No. 5. 
who qualifies as a Metis for the purpose of asserting s. 35 rights, and the relevant time frame for identifying historical customs, practices, and traditions that invoke s. 35 protection. ${ }^{7}$

Powley is a momentous and ground-breaking decision for Metis peoples who, despite their inclusion in s. 35 of the Constitution Act, 1982, have been excluded from federal claims processes, denied recognition by both levels of government as a distinct Aboriginal people with constitutionally protected Aboriginal rights, and struggle for a place at negotiation tables. Arthur Pape, co-counsel for the Powleys, suggests that Powley is "for the Métis what $R$. v. Sparrow ... was to the Indian people." In an interview for The Lawyers Weekly he explains, "[t]he court has now made it possible for ... interests in the land, in resources, in self-governance to in fact be enjoyed and operate for the benefit of Métis people, as the Constitution has extended similar kinds of protections to First Nations and to Inuit."'

For these reasons there were many interveners in Powley and Blais. Interveners in Powley included the Attorneys General of Canada, Ontario, Quebec, New Brunswick, Manitoba, British Columbia, Saskatchewan, Alberta, and Newfoundland and Labrador - all jurisdictions with self-identifying Metis populations. Provincial and national Metis organizations and two non-Aboriginal organizations, the B.C. Fisheries Survival Coalition and the Ontario Federation of Anglers and Hunters, also intervened. As Blais concerned interpretation of provisions in the Natural Resources Transfer Agreements ${ }^{10}$ common only to Manitoba, Alberta, and Saskatchewan, there were fewer governmental interveners. However, the Attorneys General of Canada, Saskatchewan, Alberta, and Manitoba, the Métis National Council, and the Congress of Aboriginal Peoples were among those presenting arguments. These decisions have been followed by a flurry of legal, academic, and political activity seeking to understand their broader implications for recognition and accommodation of other Metis constitutional rights. As well, Powley and Blais have prompted internal examination of provincial policy on Metis hunting rights and review of membership criteria by some Metis and non-status Indian political organizations. to determine the need and practical consequences of creating new criteria or categories of membership that distinguish between those individuals or groups that have a demonstrable ancestral connection to historic Metis communities and those that do not.

The purpose of this case comment is to review the specific rulings in Powley concerning Metis Aboriginal rights to hunt for food and to introduce some of the broader implications for recognition of a wider range of s. 35 Metis rights that extend beyond the borders of October 2003) 1 at 24. The reference here is to R. v. Sparrow, [1990] 1 S.C.R. 1075, 3 C.N.L.R. 160 [Sparrow cited to C.N.L.R.], which is the first decision by the Supreme Court to interpret the meaning. scope, and nature of the constitutional protection offered to $\mathrm{s}$. 35 Aboriginal rights. lbid.

11) The Agreement was passed as three separate Acts in the Prairic Provinces: Alberta Natural Resources Act, S.C. 1930, c. 3; Saskatchewan Natural Resources Act, S.C. 1930, c. 41 .; and Manitoba Natural Resources Act, S.C. 1930, c. 29 [NRTA(s)]. 
Ontario." We begin by considering the potential impact of the decision on federal and provincial consultation and negotiation with Metis representative organizations and governments. We then set out the general framework for establishing Aboriginal rights, emphasizing those aspects that are analogous to the rights of First Nations and Inuit. This is followed by an elaboration of fundamental principles unique to the Metis and normative questions about how these more liberal principles can be reconciled with the continued strict application of Van der Peet to First Nations. ${ }^{12}$ We conclude by introducing some of the difficult issues raised when Powley and Blais are applied to the assertion of a Metis commercial right to hunt in Alberta.

\section{Compelling Conversation}

According to Jean Telliet, lead counsel for the Powleys:

The most pragmatic and important consequence of this case is that it gives Métis people of Canada the opportunity to create a relationship with governments that will provide the foundation for working out all the issues that need to happen, and it is the creation of that relationship that has been denied up until now by government. $^{13}$

The opportunity for relationship building is sourced not only in the recognition of Metis constitutional rights, but also in the confirmation that the fiduciary relationship between the Crown and Aboriginal peoples extends to the Metis. The guarantee offered by s. 35 of the Constitution includes recognition of this relationship and specific fiduciary duties used to measure the validity of government interference with Aboriginal constitutional rights. ${ }^{14}$ If $\mathrm{s}$. 35 rights are infringed by federal or provincial legislation, such infringement must satisfy a justification test consisting of two parts. First, the infringement must be in furtherance of a compelling and substantial legislative objective. Second, in fulfilling that objective the Crown must act in a manner consistent with its fiduciary obligation. ${ }^{15}$ The standard of scrutiny of government action, the content of the duty, and the extent to which the Aboriginal right in issue must be accommodated is context- and fact-specific, depending largely on the legislative objective asserted and the nature of the Aboriginal right at stake. However, even when an infringement can be justified, there is always a duty to consult and involve Aboriginal peoples in decisions that affect their rights. ${ }^{16}$ When access to resources are in issue, this duty does not always demand that Aboriginal rights be given priority over other rights. This is particularly the case if the Aboriginal right does not have an internal limitation,

11 A few ideas in this comment are taken with the permission of LexisNexis Canada Inc. from a more detailed essay by Catherine Bell on Powley and Metis Aboriginal rights. See Catherine Bell, "Towards an Understanding of Métis Aboriginal Rights: Reflections on the Reasoning in R. v. Powley" in J. Magnet \& D. Dorey, eds., Aboriginal Rights Litigation (Markham: LexisNexis Butterworths, 2003) 387 [Bell, "Reflections on Powley"]. See <www.lexisnexis.ca $>$ for further information on this publication. R. v. Van der Peet, [1996] 2 S.C.R. 507, 4 C.N.L.R. 177 [Van der Peet cited to C.N.L.R.]

Schmitz, supra note 8 at 1.

Sparrow, supra note 8 at 81 and Delgamuukw v. British Columbia, [1997] 3 S.C.R. 1010, [1998] 1 C.N.L.R. 14 at 75-79 [Delgamuukw cited to C.N.L.R.].

15 The justification test was first articulated in Sparrow, ibid. at 184 and 187 and is elaborated by subsequent decisions of the Supreme Court.

16. Delgamuukw, supra note 14. The following discussion of fiduciary principles is summarized in that case. 
such as hunting for sustenance only. However, at a minimum, the allocation and process for allocation of resources attracting Aboriginal rights protection must reflect the prior Aboriginal interest. ${ }^{17}$ Only in rare cases does the duty of consultation amount to "no more than a duty to discuss" and, even then, consultation must be "in good faith, and with the intention of substantially addressing" the concerns of Aboriginal peoples whose rights are in issue. ${ }^{18}$ In some cases full consent may be required, "particularly when provinces enact hunting and fishing regulations in relation to Aboriginal lands." 19

The standard of conduct and consultation called for by s. 35 is not considered a lawful obligation by federal or provincial governments in their relations with the Metis, as both governments have consistently rejected the view that Metis have "existing" Aboriginal rights attracting s. 35 protection. This denial is sourced in what the Royal Commission on Aboriginal Peoples identified as "the mistaken view that there are only two major groups of Aboriginal peoples in Canada, First Nations and Inuit" and has perpetuated the "most basic current form of governmental discrimination." ${ }^{20}$ As explained in earlier writings:

The refusal to extend this relationship to the Métis arises from numerous sources including: debates between federal and provincial governments concerning jurisdiction over the Métis; emphasis on s. 91(24) of the Constitution Act, 1867 as the primary source of federal fiduciary duties and interpretation of this section to exclude the Métis; characterization of the exercise of government power over Aboriginal title land as a prerequisite of the fiduciary relationship and denial of Métis Aboriginal title; entrenched government policy that Métis rights, if they existed, have been extinguished; and concerns about the extension of the fiduciary relationship to Métis on the financial resources of government. As a result, any legal rights, programs, or services extended to the Métis by federal and provincial governments are considered implementation of social welfare policy and acknowledgement of economic disadvantage. Alternatively, they are viewed as actions designed to further political and economic interests, not recognition of Métis Aboriginal rights. Another practical consequence is exclusion of Métis peoples from federal processes designed to address claims arising from breach of their lawful obligations. Métis are included in federal and provincial consultations on legislation that may affect them only to the extent that it is deemed politically expedient and morally necessary. ${ }^{21}$

Powley makes it clear that both federal and provincial governments will now be held to a higher standard of conduct in their dealings with the Metis and that a denial of fiduciary obligations, at least in the area of sustenance hunting rights, must end. The Supreme Court

R. v. Gladstone, [1996] 2 S.C.R. 723, 4 C.N.L.R. 65 at 92 [Gladstone cited to C.N.L.R.].

Delgamuukw, supra note 14 at 79.

Ibid.

Report of the Royal Commission on Aboriginal Peoples, Vol. 4, c. 5 "Métis Perspectives" (Ottawa: Ministry of Supply and Services, 1996) (Co-Chairs, R. Dussault \& G. Erasmus) at 199 and 219 [RCAP Report].

Bell, "Reflections on Powley," supra note 11 at 413 [footnotes omitted]. An exception is the province of Alberta which has passed legislation establishing a form of Metis self-government on Metis settlement lands and requiring consultation on certain areas of law. However, this is not based on recognition of Metis Aboriginal rights. With respect to hunting, see e.g. Metis Settlements Act, R.S.A. 2000, c. M-14, s. 226; and Catherine Bell, Alberta's Metis Settlements Legislation: An Overview of Ownership and Management of Settlement Lands (Regina: Canadian Plains Research Center, 1994) at 72-74 [Bell, Settlements Legislation]. See also the Constitution of Alberta Amendment Act. 1990. R.S.A. 2000, c. C-24, which provides in its preamble that nothing in the Metis Settlements legislation is intended to "abrogate or derogate from any aboriginal rights referred to in section 35 of the Constitution Act. 1982." 
affirms that a "lack of recognition" of the Powleys' right to hunt for food, an absence of special access rights for the Metis in Ontario's hunting legislation, and a consequent application of that legislation to the Powleys rendering it unlawful for them to hunt without a licence infringe their Aboriginal right to hunt. ${ }^{22}$ Even if Ontario had presented sufficient evidence to justify regulation of Metis hunting for public safety or conservation purposes, the provincial government would still have a duty to consult and, because the right to hunt for food has an internal limitation, "the Métis would still be entitled to a priority allocation to satisfy their subsistence needs." 23 In the opinion of the Court, "[i]n the longer term, a combination of negotiation and judicial settlement will more clearly define the contours of the Métis right to hunt." ${ }^{24}$ Until then, the Court directs that the hunting rights of the Metis in Ontario "track those of the Ojibway in terms of restrictions for conservation purposes and priority allocations where threatened species may be involved." 25

Although the Court recognizes that the evolution of Metis political organizations creates challenges in determining who should be at the negotiation table and whether all of their members are entitled to exercise s. 35 Metis rights, the all too familiar excuses relating to the uncertainty of Metis identity and the difficulty of determining the appropriate Metis organization to consult are rejected as justifications for ignoring Metis constitutional rights. However, the Supreme Court emphasizes that as "Métis communities continue to organize themselves more formally and to assert their constitutional rights, it is imperative that membership requirements become more standardized so that legitimate rights-holders can be identified" 26 and states that the "development of a more systematic method of identifying Métis rights-holders for the purpose of enforcing hunting regulations is an urgent priority."27 This is best taken as a direction to both governments and Metis organizations, given the absence of a legislated framework analogous to the Indian Act to identify and register Metis, ${ }^{28}$ lack of government support to develop clear criteria and effective mechanisms to identify Metis (such as a provincial or national census), and shifts in Metis self-identification resulting from inconsistent application and changes in requirements for Indian status. However, "[n]o matter how a contemporary community defines membership, only those members with a demonstrable ancestral connection to the historic [Metis] community can claim a s. 35 [Metis] right." ${ }^{.29}$ Thus, Powley requires examination of membership criteria by

$22 \quad$ Powley, supra note 2 at para. 47.

Ibid. at para. 48.

Ibid. at para. 50 .

Ibid.

Ibid. at para. 29.

Ibid. at para. 49.

The exception again is Alberta, where settlement legislation defines Metis for the purpose of membership in the Metis settlements and creates specific local and regional government institutions for Metis living on settlement land (see Metis Settlements Act, supra note 21).

Powley, supra note 2 at para. 34 (S.C.C.). As explained in greater detail below, the fact that an ancestor at one time accepted the benefits of Indian treaty and acquired status under federal Indian legislation is not a fatal disruption to a claim to ancestral connection asserted by an individual who identifies as Metis, who is a member of a contemporary Metis organization, and can establish some ancestral connection to a historic Metis community that continued to exist off reserve. This was the situation of the Powleys. Consequently, some individuals with Metis ancestry may have a choice between identifying as Metis and exercising Metis constitutional rights, being reinstated as status Indians under amendments to the Indian Act, R.S.C. 1985, c. I-5, designed to address involuntary loss, or claiming dual citizenship for the exercise of different rights. 
Metis organizations, identification of those who meet the judicial definition of a s. 35 Metis person, consideration of arguments to establish sufficient connection to a historic Metis community by "other means," and determination of which members may need to affiliate with other contemporary Aboriginal collectivities in order to assert their s. 35 Aboriginal rights. ${ }^{30}$ Some of the particular challenges faced by contemporary Metis organizations seeking to assert s. 35 rights are discussed in further detail below. ${ }^{31}$ Such challenges should not be used as a justification for refusing to consult. Rather, Powley suggests that the creation or affirmation of reliable and systematic methods for identifying Metis rights-holders is the place where conversation should begin, resources should be provided, and agreements should be sought.

Although the specific facts in Powley concern the right of descendants of an historical community in Sault Ste. Marie to hunt for food, the Supreme Court also notes that fishing, trapping, and gathering were activities integral to that community. ${ }^{32}$ The decision also stands for the more general proposition that Metis rights are sourced in any practice, custom, or tradition integral to "the Métis community's distinctive existence and relationship to the land." ${ }^{\prime 33}$ This supports extending conversation beyond the issues of identification and hunting to other areas where existing and proposed provincial or federal regulation infringes, or may potentially infringe, other Metis practices or interests in land that might reasonably invoke s. 35 protection. Lower courts debate when the duty to consult on such matters arises and many provinces assert that as a matter of law the duty does not arise until an Aboriginal right is actually negotiated or established before the Court. However, regardless of the legal debate, governments often consult with Aboriginal peoples as a matter of political pragmatism to maintain positive relationships and avoid unnecessary litigation. Powley suggests that this process should now extend to the Metis.

The extent to which federal and provincial governments will expand existing policies and dispute resolution processes designed to address lawful obligations to First Nations and Inuit peoples is yet to be seen. Governments concerned about the economic and social costs of expansion may refuse to move forward absent a systematic method for identifying rightsholders and their political representatives. They may interpret Powley as placing primary responsibility for this on Metis organizations with limited financial resources. They may also emphasize that Aboriginal rights are community-and context-specific, thereby limiting any discussions to the narrow issue of sustenance hunting. Some governments may take an even narrower view and say that $P$ owley does not apply outside the specific factual context of the case. The fact that the Metis community in Sault Ste. Marie can establish a constitutional right to hunt for food does not mean that Metis communities elsewhere will be able to meet the burden of proof articulated in Powley. However, the general language used in Powley to discuss a Metis right to hunt and the principles it offers to establish Metis Aboriginal rights suggest that such a restrictive reading is contrary to the intent of the Court. Although some jurisdictions, like the province of Alberta, may have already consulted on provincial laws

Powley, ihid. at para. 32 .

See infra our discussion of "Fundamental Principles Uniçue to the Metis."

Powley, supra note 2 at paras. 43-44.

Ibid. at para. 37. Although the Court uses the word "and" the reasoning is by analogy to First Nation and Inuit rights described as "integral to their distinctive existence or relationship to the land" (ibid. [emphasis added]). 
affecting the rights of certain Metis populations to hunt within certain territories, this in and of itself does not render Powley inapplicable. Not all affected Metis rights-holders may have been consulted. Further, the legislation compelling consultation regarding hunting on Metis settlement land is not intended to respond to, or affect in any way, Metis Aboriginal rights recognized in $\mathrm{s} .35 .{ }^{34}$ What is certain is that government departments across the country will be studying this decision and interpreting it in a way that takes into consideration the economic, social, political, and legal costs of the failure to consult.

Another complicating factor in consultations is determining which non-Aboriginal governments should be involved in the conversation. The nature of the right in question (for example, hunting migratory birds that are in federal jurisdiction), arguments for and against the inclusion of Metis people (or at least their Aboriginal rights and title, in s. 91(24) of the (Constitution), and the absence of clear and plain federal legislation purporting to extinguish Metis Aboriginal rights are all relevant factors to consider in developing appropriate consultation mechanisms. ${ }^{35}$ Given the exercise of jurisdiction over Aboriginal hunting by provincial governments, absence of federal legislation in the field, federal agreement to provincial jurisdiction, and the assumption in Powley that Ontario has jurisdiction to pass hunting laws of general application that apply to Metis, it is likely that the provinces will be the major players in future negotiations even though, as we argue below, the constitutional source for provincial jurisdiction over Metis rights to hunt is unclear.

\section{Establisinng Metis Rights: The General, Anal,ytical, Framework}

\section{A. Applichtion of Generat, Princitples}

The framework for establishing Metis rights starts with a presumption that Metis Aboriginal rights are analogous to those enjoyed by First Nations and Inuit. This means that Metis Aboriginal rights also have collective, individual, historical, and contemporary dimensions. Further, principles of law concerning onus of proof, characterization, infringement, extinguishment, and justification apply equally to Metis, Inuit, and First Nations. The requirement that $\mathrm{s} .35$ be interpreted in a purposive manner and judicial recognition of constitutional rights based in historically important features of distinctive Aboriginal societies, independent of proof of Aboriginal title, also apply.3. However, unlike other Aboriginal peoples, the historic foundations of Metis rights are ascertained post-contact

Metis Settlements Act and Bell, Settlements Legislation, supra note 21 . See also the preamble of the Constitution of Alberta Amendment Act, supra note 21 . For more information on the establishment and governance of the Metis settlements and other Metis populations in Alberta, see Joc Sawchuk. The Dynamics of Native Politics (Saskatoon: Purich Publishing. 1998); Joe Sawchuk, Patricia Sawchuk \& Theresal Ferguson, Metis land Rights in Alherta: A Political llistory (1:dmonton: Metis Association of Alberta, 1981): Tom Pocklington. The (iovernment and Politics of the Alherta Metis. Settlements (Regina: Canadian Plains Research (entre, 1991); Cattherine Bell and Metis Settlements Appeal Tribunal (MS^T), Contemporary Metis. Justice: The Settlement Way (Saskatoon: Native L aw (ientre, 1999); and Bell, Settlements Legislation, supra note 21

$\Lambda$ raised later in this comment, there are arguments for and against the extinguishment of Metis title through the scrip process. Ilowever, even if this process effectively extinguished title, it cannot be presumed that hunting rights and other $\Lambda$ boriginal rights were terminated as part of this process (sec
infra note 192).

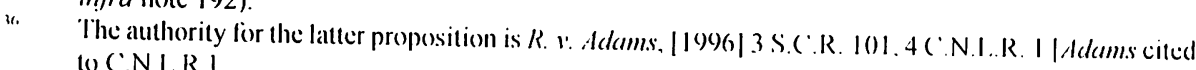
Io C.N.L.R.I. 
and Metis rights claimants must meet an identification test that has both individual and group dimensions.$^{37}$ Further, given the unique historical circumstances of the Metis, the Supreme Court has endorsed a flexible approach to assessing continuity and existence of Metis communities. ${ }^{38}$ These modifications to existing Aboriginal rights jurisprudence and their implications for Metis and other Aboriginal peoples are elaborated below in our discussion of fundamental principles unique to the Metis.

Aboriginal rights protected by s. 35 are sui generis inherent legal rights. Before Powley, most Metis rights cases developed within a contingent rights framework that seeks to find the source of Metis rights in Crown recognition through legislation, constitutional instruments, or some other means. ${ }^{39}$ An inherent rights approach accepts that Metis Aboriginal rights exist at common law independent of such acts of recognition. ${ }^{40}$ The sui generis nature of these rights means that they are not fully understood with reference to the common law; however, their form and content is also defined by the customary laws and perspectives of Aboriginal peoples. ${ }^{41}$ These rights include, but are not limited to, Aboriginal title and are sourced in the distinctive cultures of Aboriginal peoples and their relationship to the land. Aboriginal rights are also context- and fact-specific. To the extent that Aboriginal cultures share similar historical features, the contents of their rights are the same. However, differences in historical practices, customs, and traditions integral to distinctive Aboriginal societies give a unique shape to rights of specific Aboriginal communities. Although there is some overlap, different principles of law have developed pertaining to Aboriginal title and to rights which are not asserted as part of a title claim. As the hunting rights asserted in Powley were not associated with a claim to title, the Court drew on these principles to develop an analytical framework for establishing Metis rights based in specific historical customs, practices, and traditions. In particular, it applied Sparrow and a modified version of the principles in Van der Peet to "reflect the distinctive history and post-contact ethnogenesis of the Metis." ${ }^{42}$

Applying Sparrow to Metis Aboriginal rights claims, the onus is on the Metis individual or group asserting the s. 35 right to demonstrate the existence of an inherent Metis right prior to 1982 and the infringement of that right. The onus is on the Crown to prove extinguishment prior to 1982 or to justify interference according to the tests described above. The collective, individual, historic, and contemporary nature of Aboriginal rights affects elements of the existing rights that must be proven. As elaborated in other writings on this topic:

37 Powley, supra note 2 at paras. $31-34,38$, and 40 (S.C.C.).

is $\quad$ bid. at paras. $24-28$.

3) See R. v. Laprise (1977) 9 C.N.L.C. 634, [1977] 3 W.W.R. 379 (Sask. Q.B.), aff'd (1978) 9 C.N.L.C. 638, [1978] 6 W.W.R. 85 (Sask. C.A.); R. v. Grumbo (1996), 146 Sask. R. 286, [1996] 3 C.N.L.R. 122 (Sask. Q.B.), rev'd (1998) 168 Sask. R. 78, [1998] 3 C.N.L.R. 172 (Sask. C.A.) [Grumbo cited to C.N.L.R.]; R. v. McPherson (1992), 82 Man. R. (2d) 86, 4 C.N.L.R. 144 (Man. Prov. Ct.) [McPherson cited to C.N.L.R.]; R. v. Ferguson, [1993] 2 C.N.L.R. 148, [1998] A.J. No. 190 (Alta. Prov. Ct.), aff'd [1994] 1 C.N.L.R. 117, [1993] A.J. No. 1064 (Alta. Q.B.) (QL) [Ferguson cited to C.N.L.R.]. contingent rights approaches to Metis rights, see Bell, "Reflections on Powley," supra note 11 at 394 401 .

41 See for example, Delgamuukw, supra note 14 at 71 where Lamer J., speaking for the Supreme Court of Canada notes that Aboriginal perspectives can be ascertained from their "traditional laws, because those laws were elements of practices, customs, and traditions of Aboriginal peoples."

4: $\quad$ Powley, supra note 2 at para. 14. 
Aboriginal rights are communal rights that attach to Aboriginal communities and, depending on the nature of the right, are exercised by individuals who are members of those communities. Although Aboriginal rights are grounded in practices and traditions of historical Aboriginal communities, they are exercised today by contemporary communities that exist in continuity with historic communities. For these reasons, it was necessary for Steve and Roddy Powley (the respondents) to establish membership in a contemporary Métis community in continuity with a historical Métis community in the area of Sault Ste. Marie. In response to arguments raised by the appellants and definitions of Métis adopted by the lower courts, they also had to establish ancestral continuity and family connection with the historic Métis community. ${ }^{43}$

The first step in proving the existence of an Aboriginal right is to characterize the right being claimed. Applying Van der Peet, the Supreme Court concludes that like other s. 35 Aboriginal rights, Metis rights are "contextual and site-specific," meaning that the right to hunt must be articulated in relation to a specific historical and contemporary Metis community, a particular custom, tradition, or practice and to a particular territory. ${ }^{44} \mathrm{Van}$ der Peet requires that consideration also be given to "the nature of the action which the applicant is claiming was done pursuant to an Aboriginal right, the nature of the governmental regulation, statute or action being impugned, and the tradition, custom or practice being relied upon to establish the right." ${ }^{45}$ As a result, the lower courts debate as to whether the proper characterization of the right asserted in Powley is the right to hunt for food or the right to hunt moose for food as asserted by the Attorney General of Ontario. The Crown relied on the R. v. Pamajewon ${ }^{46}$ decision released by the Supreme Court the day after Van der Peet. However, the lower courts in Powley held that the Crown's characterization placed too much emphasis on the impugned statute and not enough on the Aboriginal perspective. At the Court of Appeal, Sharpe J. explained that Pamajewon is properly understood as supporting the principle that s. 35 rights must be defined "at the appropriate level of specificity" necessary to avoid "excessive generality." 47 Justice Sharpe notes that it is hard to argue that hunting for food is an excessively general characterization when the Supreme Court has with "striking regularity characterized claims as the right to hunt and fish for food, without reference to a specific species." 48 The Supreme Court agrees that the "relevant right is not to hunt moose but to hunt for food in the designated territory." 49

The second part of the Van der Peet test provides that contemporary rights must be based on practices, customs, and traditions that exist in continuity with practices, customs, and traditions integral to an Aboriginal society prior to European contact. Section 35 protects central, significant, and defining distinctive features of Aboriginal societies. A way of

4) Supra note 2 at para. 20. For a more detailed discussion of this and the second part of the test in the

following paragraph, see Bell. "Reflections on Powley," supra note 11 at 404-407.

Bell, "Reflections on Powley," supra note 11 at 390-91.

Powley, supra note 2 at para. 19.

Supra note 12 at 203.

[1996] 2 S.C.R. 821, 4 C.N.L.R. 164 [Pamajewon cited to C.N.L.R.].

Supra note 2 at para. 109 (Ont. C.A.), quoting Pamajewon, ibid. at 172. The facts in that case concerned high stakes bingo on reserve lands. The Aboriginal rights raised in response to charges laid against the accused for unauthorized gambling were the right to self-government and use and management of traditional lands. Although the Courts have indicated willingness to entertain claims relating to aspects of governance, they have only entertained claims based on title or particular practices, traditions and customs (see e.g. Delgamuukw', supra note 14 at 80-81).

Powley, ibid. at para. 114. 
determining the integral nature of a custom, practice or tradition is to ask "whether, without this practice, tradition or custom, the culture in question would be fundamentally altered or other than it [was]. ${ }^{" 50}$ Some European influence is tolerable, however, not to the extent that European influence is solely responsible for the activity in issue..$^{51}$ In relation to First Nation and Inuit Aboriginal rights claims, the date to ascertain the integral nature of the practice, tradition, or custom is the time of contact because it is the "fact that distinctive Aboriginal societies lived on the land prior to the arrival of Europeans that underlies the Aboriginal rights protected by s. 35(1)."52 Speaking for the majority in Van der Peet, Chief Justice Lamer acknowledged that it may be inappropriate to apply this reasoning to the Metis as the "history of the Métis, and the reasons underlying their inclusion in the protection given in $\mathrm{s}$. 35, are quite distinct from those of other Aboriginal peoples of Canada." 5.3 As we discuss below, Powley takes the signal from Van der Peet and elaborates these reasons while developing principles of law unique to the Metis.

Although there must be continuity between the activity claimed as a modern right and precontact practice grounding the right, the test for continuity does not demand an unbroken chain of practice from the pre-contact period to the present. Interruptions in the activity are permissible. ${ }^{54}$ Thus, a break or change in practice because of scarcity of game in the early 19th century in the relevant hunting territory was not a fatal gap in continuity for the Powleys. As we elaborate below, the concept of continuity is also applied for the first time to identification of a contemporary rights-bearing Aboriginal community. The issue has not yet arisen in the First Nation context because of their different historical treatment and the recognition of formal legal communities by the federal government. As O'Neil J. of the Ontario Superior Court explains:

It is not so easy to package up and describe a Métis community, as is the casc, by comparison with, lor example, a recognized Indian band occupying recognized reserve lands as delined under the Indian Act, R.S.C.' 1985, c.1-5. (jiven the governments' treatment of Métis people, it may seldom be the case that Métis rights will be found where there is a flourishing Métis community, as opposed to one that is only now beginning to put back together aspects of its culture. This is recognized by the federal government, which admitted in its Statement of Reconciliation in 1998 that Metis people suffered at the hands of government policy. ${ }^{55}$

Once an Aboriginal right is established, the onus is on the Crown seeking to infringe the right to show that it has not been extinguished. It is beyond the scope of this comment to review the law of extinguishment. However, it is important that Powley notes that the

Supra note 12 at 204.

Ihid. at 209-10.

Ihid. at 205. There has been substantial academic criticism concerning the selection of the date of contact to identify historical practices, customs, and traditions of lirst Nations. Prior to l'an der Peet. the date used in Aboriginal rights and title jurisprudence was the assertion of sovereignty. $\Lambda$ s a consequence, different dates are selected to ascertain historical foundations of $A$ boriginal title and other rights claims. We raise a few criticisms relating to this point and illustrate how inequities may arise as the result of selecting yet a different date for Metis rights claims.

is $\quad$ lhid. at 207

is Ihid. at 206. The points on continuity that follow were first raised, and are elaborated in. Bell, "Reflections on Powley," supra note II at 408-12.

is Supra note 2 at 245. 
"doctrine of extinguishment applies equally to Métis and to First Nations claims." "56 The Crown argued that the Robinson Huron Treaty extinguished the rights of the Metis in the area of Sault Ste. Marie even though the Metis, as a group, were not parties to it. This argument is consistent with federal policy that a treaty extinguishes title to the geographical areas it covers and that those First Nations who may have been missed in the treaty signing process, or were not properly represented for some reason, have the option to adhere to the treaty. ${ }^{57}$ Further, the Powleys' ancestors were signatories to the Robinson Huron Treaty and lived on a reserve as status Indians for a period of time. However, evidence supported that such people were still considered part of the Metis community by government officials and that recommendations were made to take them off the treaty list. Whatever the rationale behind the Crown's argument, it is rejected by the Supreme Court, which emphasizes, in agreement with the lower courts, that "the individual decision by a Métis person's ancestors to take treaty benefits does not necessarily extinguish that person's claim to Métis rights. It will depend, in part, on whether there was a collective adhesion by the Métis community to the treaty." 58 It will of course also depend on whether that person meets the criteria to identify as a rights-bearing Metis person articulated elsewhere by the Court.

\section{B. JURISDICTION, EXTINGUISHMENT AND REGULATION}

Although not argued in Powley and Blais, complex questions concerning the ability of provinces to regulate Metis hunting arise when these cases are considered together with the jurisdictional analysis and most recent statement on the law of extinguishment in Delgamuukw. In Delgamuukw, the Supreme Court held that s. 91(24) of the ('onstitution Ac't. 1867, which gives the federal government jurisdiction over "Indians, and Lands reserved for Indians," includes within it the "exclusive power to extinguish Aboriginal rights, including Aboriginal title." 59 The reasoning is sourced in basic principles of constitutional interpretation and in s. 88 of the Indian Act ${ }^{(0)}$ Jurisdiction vested in the federal government under s. 91(24) operates to preclude provincial laws from applying to matters considered to be at the core of federal jurisdiction under this section. Thus, provincial laws that are primarily in relation to Indians are ultra vires. Provincial laws of general application ${ }^{(1)}$ do

Ibid. at para. 46 (S.C.C.).

This policy has some support in Ontario (A.G.) v. Bear Island Foundation, |1991| 2 S.C.R. 570, 3 C.N.L.R. 79. The Temagami First Nation was not a party to the Robinson Huron Treaty in 1850. In 1888, the First Nation began to receive treaty annuity payments and was also granted a reserve of one square mile on Bear Island, which neither Canada, Ontario, or the First Nation viewed as satisfying the land entitlement of the First Nation under the Robinson Huron Treaty. Furthermore, no formal surrender of Aboriginal title was ever negotiated with the First Nation. Despite these facts, the Supreme Court of Canada held that the First Nation's acceptance of annuity payments under the Robinson I luron Treaty and a reserve, constituted "arrangements" by which the First Nation had adhered to the Treaty.

Supra note 2 at para. 35

Delgamuukw, supra note 14 at 81

Supra note 29, s. 88 . This section provides:

Subject to the terms of any treaty and any other Act of Parliament, all laws of general application from time to time in foree in any provinee are applicable to and in respect of Indians in the province. except to the extent that those laws are inconsistent with this act or any order, rule, regulation or bylaw made thereunder, and except to the extent that those laws make provision for any matter for which provision is made by or under this $\mathrm{Act}$.

Provincial laws of general application are laws that extend uniformly throughout the province and are not in relation to a particular class of citizens in object or purpose (sec Kruger and Manuel v. R. . [1978] I S.C.R. 104). 
apply to Indians and their lands ex proprio vigore, but only if such laws do not touch upon the "core of Indianness" protected under s. 91(24). ${ }^{62}$ In Dick, the Supreme Court presumes that hunting is included in the core of Indianness. ${ }^{63}$ In Delgamuukw, Lamer C.J. adds that the core "encompasses Aboriginal rights, including the rights that are recognized and affirmed by s. 35(1)."64

Provincial laws of general application that would not otherwise apply to First Nations in the exercise of their Aboriginal rights are allowed to do so through the operation of s. 88 of the Indian Act, which incorporates by reference these laws as federal law. ${ }^{65}$ As explained in Delgamuukw:

What this means is that $\mathrm{s} .88$ extends the effect of provincial laws of general application which cannot apply to Indians and Indian lands because they touch on Indianness at the core of s. 91(24). For example, a provincial law which regulated hunting might very well touch on its core. Although such a law would not apply to Aboriginal people proprio vigore, it would still apply through section 88 of the Indian $\mathrm{Act}$, being a law of general application. Such laws are enacted to conserve game and for the safety of all. ${ }^{66}$

Provincial laws of general application that apply through this section, such as hunting and trapping laws, can have the effect of infringing on Aboriginal rights. Thus, the justification test discussed earlier in this comment and the fiduciary obligations arising from legislative interference with Aboriginal rights apply equally to federal and provincial governments. Even if provincial laws of general application are "necessarily inconsistent" with the continued exercise of Aboriginal rights, they do not extinguish them. ${ }^{67}$ The test for extinguishment by legislation is "clear and plain" intent. ${ }^{68}$ Chief Justice McLachlin elaborates this test in her dissenting opinion in Van der Peet:

R. v. Dick, [1985] 2 S.C.R. 309, 4 C.N.L.R. 55 at 59 and 71 [Dick cited to C.N.L.R.]. The principle of constitutional law implicated here is the doctrine of interjurisdictional immunity. Although the Supreme Court has taken into consideration the political realities of federation and general nature of constitutional language to recognize overlapping federal and provincial jurisdiction in some contexts, this dual aspect doctrine has not been applied when Aboriginal rights are in issue. The Court may also characterize a law as primarily in relation to a provincial matter or a law of general application that does not go to the core of Indianness where an Aboriginal right has not been established even if an Aboriginal population is disproportionately affected (see e.g. Kitkatla Band v. B.C. (Minister of Small Business, Tourism and Culture), [2002] 2 S.C.R. 146, 2 C.N.L.R. 143 [Kitkatla cited to C.N.L.R.]). Delgamuukw, supra note 14 at 85 . For a contrary opinion offered by the Saskatchewan Court of Appeal prior to Delgamuukw, see Grumbo, supra note 39 at 185 (Sask. C.A.), where the Court says the weight of authority states that provincial laws of general application concerning hunting do not go to the core of Indianness and although Dick, ibid. assumed they do, the Supreme Court also said in Dick that they were not deciding the issue. See also R. v. Maurice, [2002] 2 C.N.L.R. 244, [2001] S.J. No. 850 (QL), aff'd [2002] 2 C.N.L.R. 273, (2002) 1 W.W.R. 745 [Maurice cited to C.N.L.R.], a decision of the Provincial Court of Saskatchewan decided after Delgamiukw. Delgamuukw, ibid. at 83.

Ibid. at 85 .

Ibid. Note that a distinction must be drawn between Aboriginal and treaty rights to hunt as s. 88 does not give a province power to regulate in relation to treaty rights. Further, the NRTAs discussed below places limits on provincial regulatory power in this area. 
The Canadian test for extinguishment of Aboriginal rights borrows from the American test in United States v. Dion, 476 U.S. 734 (1986), at pp. 739-40: "what is essential [to satisfy the 'clear and plain test'] is clear evidence that [the government] actually considered the conflict between its intended action on the one hand and Indian treaty rights on the other, and chose to resolve that conflict by abrogating the treaty" or right. ${ }^{69}$

A provincial law that shows a sufficiently clear and plain intent to extinguish an Aboriginal right is not a law of general application and is beyond the legislative competence of the province. $^{70}$

Does the above reasoning apply to regulation and extinguishment of Metis hunting rights protected by s. $35 ?^{71}$ This question is more complicated because it is not clear if Metis and their Aboriginal rights are covered by s. 91(24) and because many self-identifying Metis people are excluded from the application of s. 88. Most academic opinion, including the Report of the Royal Commission on Aboriginal Peoples, supports the inclusion of Metis under s. 91(24). Governments were prepared to acknowledge this fact in the failed Charlottetown Accord. ${ }^{72}$ However, Blais makes it more difficult to argue that all Metis are s. 91(24) "Indians" as it emphasizes the historical context of constitutional interpretation and supports the proposition that at least some Metis communities were viewed as distinct from Indians around the time that the Constitution was negotiated. Further, the Supreme Court rejects the popular argument that there should be "continuity of language" among constitutional provisions such that all references to "Indian" are interpreted to include the modern s. 35 definition of Aboriginal peoples. ${ }^{73}$ Rather, the Court states:

[w]e do not find this approach persuasive. To the contrary, imposing a continuity requirement would lead us to conclude that "Indians" and "Métis" are different, since they are separately enumerated in s. 35(2) of the Constitution Act, 1982. We emphasize that we leave open for another day the question of whether the term

(1) Supra note 12 at 273.

70. Delgamuukw, supra note 14 at 84-85.

71 See e.g. Ferguson, supra note 39. See also Grumbo, supra note 39 (Sask. C.A.), which rejects the argument that the equivalent provision applies only to treaty Indians entitled to register under the Indian Act and that rights protected under the Saskatchewan NRTA protect Aboriginal rights exercised in relation to Crown land prior to the $N R T A$.

72 RCAP Report, supra note 20 at 209. The Accord was signed 28 August 1992. References here are to the Draft Legal Text to the Accord published on 9 October 1992. Section 91A of the Accord provided that s. 9l(24) would be amended to include all of the Aboriginal People of Canada. However concurrent and subordinate jurisdiction was given to the province of Alberta in s. 95E. which enabled Alberta and Canada to make laws in relation to Metis and settlement land in Alberta. Designed to accommodate provincial Metis settlement legislation, the proposed amendment implies Alberta is acting outside its jurisdiction. See Don McMahon \& Fred Martin, "The Métis and 91 (24): Is Inclusion an Issue?" in Royal Commission on Aboriginal Peoples, Aboriginal Self-Government: Legal and Constitutional Issues (Ottawa: Canada Communications Group, 1995) 277 at 341 . For a contrary argument see Dale Gibson, "When is a Métis an Indian? Some Consequences of Federal Constituitonal Jurisdiction over Métis" in Paul Chartrand, ed., Who Are Canada's Aboriginal Peoples? (Saskatoon: Purich Publishing, 2002) 258 at 263 [Gibson, "When is a Métis an Indian?].

73. For an elaboration of this argument see e.g. Bradford Morse \& Robert Groves, "Métis and Non-status Indians and Section 91(24) of the Constitution Act, 1867" in Chartrand, ibid. 191 at 202-204. This argument is somewhat different from that advanced in Maurice, supra note 63 at 252, where it is argued that "continuity of language in both government correspondence and legislation" support the conclusion that framers of the NRTA intended to include Metis when they used the term "Indian." 
"Indians" in s. 91(24) of the Constitution Act. 1867 includes the Métis - an issue not before us on this appeal. ${ }^{74}$

Despite these challenges, Powley and Delgamuukw suggest that Metis Aboriginal rights are within core federal jurisdiction under s. 91(24), regardless of whether Metis are "Indians" within the meaning of that section. Powley recognizes a Metis Aboriginal right to hunt and states that " $[\mathrm{t}]$ he doctrine of extinguishment applies equally to Metis and to First Nations claims." Delgamuukw provides that Aboriginal rights are part of the core of Indianness protected in s. 91(24) and that as a result they cannot be extinguished by provincial legislation. $^{76}$ It follows that if the Metis have Aboriginal rights and the doctrine of extinguishment applies equally to them, their Aboriginal rights are also within the scope of s. 91(24). However, Powley does not elaborate on issues of jurisdiction or provide reasons for extending the doctrine of extinguishment to the Metis. As these issues have yet to be raised directly before the Supreme Court, the rationale for applying this doctrine and the issue of Metis inclusion under s. 91(24) remains open to debate.

If we accept that Metis Aboriginal rights are matters of core federal jurisdiction, can provincial laws of general application concerning hunting apply to the Metis in Alberta? Absent an Act of Parliament that incorporates by reference provincial law into federal law, the answer to this question may be no. It depends in part on who we mean by Metis, whether the Metis fall within the definition of "Indians" under s. 88 of the Indian Act, and whether the ruling in Blais concerning the scope of the hunting provisions under the NRTA applies outside Manitoba. One might argue that if Metis and their rights are included under s. 91(24), s. 88 should also apply to them. The practical purpose of s. 88 is to avoid a legislative vacuum and the necessity of enacting federal legislation in areas occupied by the provinces where federal policy is to treat Aboriginal peoples the same as other citizens. Further, Metis that engaged in an "Indian way of life" were entitled to status under old versions of the legislation and, in one instance, an entire Metis community acquired Indian status under federal Indian legislation. ${ }^{77}$ There are also Metis communities "in Ontario or elsewhere outside of the Prairie Provinces, the Northwest Territories, and northeastern British Columbia [that] have never been formally excluded from the Indian Act because they are not connected to the land-grant system under federally constituted Half-breed Scrip Commissions and the Dominion Lands Acts." ${ }^{78}$ However, it is difficult to argue that a section included in legislation which expressly excluded "half-breeds" with scrip history from its operation applies to Metis or to any Metis with scrip history. Section 88 was first enacted in $1951 .^{79}$ At that time, the Indian Act also excluded persons who "received or [had] been allotted half-breed lands or

Supra note 5 at para. 36.

Supra note 2 at para. 46 (S.C.C.).

Supra note 14 at 83 .

The community referred to here are the Metis of Fort Francis, Ontario who accepted Treaty 3 at Fort on the 12 September 1875 by way of an adhesion to the Treaty titled: Adhesion by Halfbreeds of Rainy River and Lake (A.), online: Indian and Northern Affairs Canada <www.ainc-inac.gc.ca/pr/trts/ trty3_e.html>.

John Giokas \& R. Groves, "Collective and Individual Recognition in Canada: The Indian Act Regime" in Paul Chartrand, supra note 72,41 at 46.

It was then s. 87 (Peter Hogg, Constitutional Law of ('anada, 2002 Student Edition (Scarborough: Thompson Canada Ltd., 2002) at 589). 
money scrip" and their descendants. ${ }^{80}$ As s. 88 is part of the Indian Act, and Metis with scrip history are not within the definition of Indians covered by the Act, they are also excluded from the operation of s. $88 .^{81}$ Thus, the majority of Canada's Metis population and, by definition, all members of the Métis Nation, would be excluded from the operation of s. $88 .{ }^{82}$ If one accepts this line of reasoning, $s .88$ cannot be viewed as a source of provincial power to regulate the hunting rights of Metis communities or individuals connected with the scrip system. However, a definitive position on the scope of s. 88 can only be ascertained by examining the historical context and purpose for its inclusion in the Indian Act and, if Blais operates as a guide to statutory interpretation, "the prevailing understandings of Crown obligations and the administrative regimes that applied to the different Aboriginal groups" in Canada at the time. ${ }^{83}$

Provincial regulatory power over Aboriginal hunting rights in the Prairie Provinces is also sourced in and limited by the NRTAs which provide:

In order to secure to the Indians of the Provine the continuance of the supply of game and fish for their support and subsistence, Canada agrees that the laws respecting game in foree in the Province from time to time shall apply to the Indians within the boundaries thereof, provided however, that the said Indians shall have the right, which the Province hereby assures to them, of hunting, trapping and fishing game and fish for food at all seasons of the year on all unoccupied Crown lands and on any other lands to which the said Indians may have a right of access. ${ }^{84}$

Although this paragraph allows a province to regulate hunting that affects Aboriginal rights, it must do so subject to the specific promises contained therein and to the guarantees protected in s. 35 of the Constitution Act, 1982. These rights may also be subject to limitations, such as hunting in a reasonable and safe manner. ${ }^{85}$

The Supreme Court in Blais holds that the Manitoba Metis are not included in the definition of Indian under this paragraph in the Manitoba NRTA. The Court reasons that a statute, including one of constitutional force, "must be interpreted in accordance with the meaning of its words, considered in context and with a view to the purpose [it was] intended to serve." ${ }^{, 80}$ Although constitutional statutes require generous and prospective interpretation, a court is not "free to invent new obligations foreign to the original purpose of the provision at issue. The analysis must be anchored in the historical context of the provision." ${ }^{17}$ The Court considers the "linguistic, philosophic, and historical contexts" of the provision,

Indian Act, R.S.C. 1951, c. 29, s. 12(1)(a)(1). At this time, references to "Indian blood" and "mode of life" were replaced. The scrip history exclusion remained in place until amendments to status recognition provisions under in 1985. However, as a matter of policy, the federal government still refuses to grant status to people with scrip history. John Giokas \& Paul Chartrand, "Who are the Metis in Section 35?: A Review of the Law Relating to Métis and 'Mixed-Blood' People in Canada" in Chartrand, supra note 72,83 at 94 .

${ }^{81} \quad$ Hogg, supra note 79 at n. 64 and Maurice, supra note 63 at 260-61.

*2 See infra notes 160-61

*3. Supra note 5 at para. 19 (S.C.C.).

x. Supra note 10 at para. 13 in the Manitoba NRTA and para. 12 in Saskatchewan and Alberta NRTAs. 
including "prevailing understandings of Crown obligations and the administrative regimes that applied to the different Aboriginal groups in Manitoba." ${ }^{" 88}$ It concludes that the NRTA was an administrative transfer of responsibilities under which the Crown viewed its obligations to the Metis as different from its obligations to Indians. The fundamental concern was to protect "those who automatically or voluntarily became subject to, or beneficiaries of, the Indian Act." ${ }^{.80}$

It is not clear if the reasoning in Blais will be extended to equivalent provisions in the Alberta and Saskatchewan NRTAs. However, there are several arguments why it should. Specifically, the following factual conclusions are cited by the Court in support of its finding:

1. The purpose of paragraph 13 of the NRTA is "to protect the hunting rights of the beneficiaries of Indian treaties and the Indian Act." 90

2. The placement of paragraph 13 in the NRTA under the heading "Indian Reserves" and with two other passages that clearly have no relevance to the Metis, are strong indications that the Metis are not "Indians" under paragraph 13. ${ }^{91}$

3. Generally, the Metis could choose whether to take treaty and/or membership in an Indian band; in other words, they could choose Indian or Metis identity. Indians had no such choice. Therefore, Metis identity is a result of "an individual act of voluntary association." 92

4. The Manitoba Act, 1870 provided for the extinguishment of Metis "Indian" title by way of scrip. That Metis title was dealt with separately and uniquely from the title held by Indians is evidence that the Metis were not considered "Indians."

5. The history of the Metis in Manitoba supports the conclusion that, prior to and at the time of the passage of the NRTA, the Metis and others viewed them as a distinct group of people from Indians. ${ }^{93}$

The wording of para. 12 of the Alberta and Saskatchewan NRTAs is identical to para. 13 of the Manitoba NRTA.$^{94}$ Therefore, it is reasonable to conclude that the purpose of para. 12 is the same as that of para. 13, which in Blais the Court finds to be protection of treaty and status Indian hunting rights. ${ }^{95}$ It is also important that para. 12 falls under the heading "Indian Reserves" and is found with the same two passages relating to Indians as those under consideration in Blais. ${ }^{96}$ Moreover, the Supreme Court emphasizes that because the Metis in Manitoba could choose to identify as Indian or Metis, this distinguished them from Indians who had no such choice. ${ }^{97}$ There is ample historical evidence that the Metis in Alberta and 
Saskatchewan had similar opportunities to exercise "an individual act of voluntary association. ${ }^{198}$ During the Scrip Commissions of the late 1800s and early 1900s in Alberta and Saskatchewan, numerous Metis voluntarily withdrew from treaty in order to apply for scrip. ${ }^{99}$ This option was not available to Treaty Indians. Furthermore, Metis were given a choice between taking treaty or scrip in 1899 when the Treaty 8 Commission made its way through northern Alberta. ${ }^{100}$ Finally, the Court in Blais finds that the provisions of the Manitoba Act relating to the distribution of land to the Metis by way of scrip was another indication that the Metis were treated differently than the Indians. ${ }^{101}$ The same method, the issuance of scrip, was used under the Dominion Lands Act in Alberta and Saskatchewan. ${ }^{102}$ All of these factual similarities to the Manitoba Metis in Blais support the conclusion that Blais applies in Alberta and Saskatchewan. For these reasons, the NRTA may not be a source of provincial jurisdiction over Metis hunting nor, as it has been argued in the context of First Nation rights, can it be viewed as federal extinguishment or modification of Metis hunting rights. ${ }^{103}$

On the other hand, equally persuasive arguments exist to distinguish Blais and render it inapplicable to Alberta and Saskatchewan. Acceptance of these arguments would clarify the source of provincial jurisdiction over Metis hunting in these provinces and, as argued below, would be relevant to the extinguishment and survival of commercial rights to hunt. Particular emphasis is given in Blais to the unique history of the Manitoba Métis Nation who were "at the forefront of seeking self-government in the Red River area, the distinction drawn by government and Hudson's Bay officials between Indians and Metis before and after the Riel Resistence of 1870 , and petitions to the government for the creation of half-breed associations in northern Manitoba in 1831." ${ }^{104}$ Thus, those responsible for drafting the Manitoba NRTA were "quite conscious of the distinction recognized between Indian and Métis" and it is not "credible to believe that the word 'Indian' would be used" with the intention of including the Métis. ${ }^{105}$ It is possible that there was a greater appreciation of Metis as a separate and distinct people in southern and central Manitoba before such appreciation developed in other Prairie Provinces, particularly in the northern regions where government officials had a difficult time distinguishing between Indians and Metis. Indeed, the Alberta Court of Queen's Bench has included Metis individuals who live an Indian way of life (that

Ibid. at paras. 22-24. It is worthy of note that the scrip was also distributed on a smaller scale to Metis in Montana, British Columbia, and the Northwest Territories under the Dominion Lands Act. 1879. S.C. 1879, c. 31

Kenneth J. Tyler, A Tax-Eating Proposition: The History of the Passpasschase Indian Reserve (M.A. Thesis, University of Alberta, Department of History, 1978) [unpublished] at 81-82. David Leonard \& Beverly Whalen, eds., On the North Trail: The Treaty 8 Diary of O.C. Edwards (Calgary: Alberta Records Publication Board and Historical Society of Alberta, 1988) at 53. Supra note 5 at para. 34 (S.C.C.)

Pocklington, supra note 34 at 6 .

10.3 See Frank v. The Queen, [1978] 1 S.C.R. 95 at 100, [1997] 4 W.W.R. 294 [Frank cited to S.C.R.]; Moosehunter v. The Queen, [1981] I S.C.R. 282 at 285. (1981), 9 Sask R. 149 [Moosehunter cited to S.C.R.]; R. v. Horseman, [1990] I S.C.R. 901 at $931-32,4$ W.W.R. 97 [Horseman cited to S.C.R.]; and R. v. Badger, [1996] I S.C.R. 771 at para. 35. (1996) 133 D.L.R. (4th) 324 [Badger cited to S.C.R.]. 
is, sustenance hunting) within the definition of "Indian" under the hunting provisions of the NRTA. ${ }^{106}$ Provincial policy has been to respect this decision.

If Metis rights are within s. 91(24) and provincial regulatory powers under s. 88 of the Indian Act, and the NRTA does not extend to Metis, can provincial hunting laws continue to apply to the Metis in Alberta absent federal adoption of these laws? A strict application of the doctrine of interjurisdictional immunity suggests that the answer is no. This would be an unconstitutional invasion of core federal jurisdiction. However, before leaving this topic, the decision of Nightingale J. of the Saskatchewan Provincial Court in Maurice should be considered. ${ }^{107}$ Although decided before Blais, his reasoning with respect to the application of the doctrine of interjurisdictional immunity to provincial hunting laws may receive some support. Despite the passages in Delgamuukw quoted earlier, Nightingale J. concludes that provincial hunting laws are laws of general application that do not touch on core federal jurisdiction under s. 91(24). ${ }^{108}$ Judge Nightingale suggests that Delgamuukw does not conclusively decide that hunting laws touch upon the core of Indianness. It is best understood as standing for the propositions that: (1) provincial laws which purport to extinguish an Aboriginal right are beyond the legislative competence of a provincial government; and (2) provincial laws of general application which affect Aboriginal rights are to be examined according to the s. 35 justification tests, not the doctrine of interjurisdictional immunity. ${ }^{109}$ The assumption that provincial hunting laws apply to the Metis in Powley provides some support for this argument, as do the myriad of provincial laws that touch upon potential Aboriginal rights and the practice of the Supreme Court to interpret constitutional powers in a manner cognizant of the political realities of federation. It may be that once the various arguments are considered, hunting is considered to be an area of overlapping jurisdiction, in which case provincial law is only rendered inapplicable in the face of conflicting federal legislation. ${ }^{110}$

It is beyond the scope of this comment to explore arguments and seek sources for provincial jurisdiction over Metis hunting. The point we wish to emphasize is that the issue of jurisdiction is complex and that the source of provincial jurisdiction is unclear if Metis communities in Alberta establish an Aboriginal right to hunt. What if Metis and their rights are not within the scope of s. 91(24)? Can a province extinguish a Metis Aboriginal right? Powley says no. In any event, the issue is of purely academic interest as there were no provincial or federal laws that clearly and plainly extinguished Metis Aboriginal rights to hunt before their constitutional protection in 1982. Thus, Metis hunting rights are protected in s. 35 in their original, unregulated form. Legislative infringements of this right must meet the justification test. However, as a practical matter, given the importance of public safety and conservation, a court would likely stay the enforcement of a decision that provincial laws

106 R. v. Ferguson, supra note 39. For a fuller treatment of the history of the NRTA in the three prairie provinces, see Frank Tough, "The Natural Resources Transfer Agreements and Indian Livelihood Rights, ca. 1925-1933" (2004) 41 Alta. L. Rev. 999. See also Frank Tough, "Introduction to Documents: Indian Hunting Rights, Natural Resources Transfer Agreements and Legal Opinions from the Department of Justice," (1995) 10 Native St. Rev. at 121-67; and Maurice, supra note 63.

1117 Supra note 63.

inx Ibid. at para. 61.

III) Ibid. at paras. 58-61.

111 For an analogous argument applied to Metis settlement legislation see Gibson, "When is a Métis an Indian?," supra note 72 at 263. 
limiting Metis hunting rights are ultra vires until a constitutionally valid scheme is put in place. ${ }^{11}$

\section{Fundamental Principles UniQue to the Metis}

\section{A. Historical Foundations of Metis Aboriginal Rights}

In Van der Peet, Lamer C.J., writing for the majority of the Court, stated:

the doctrine of Aboriginal rights exists, and is recognized and affirmed by s. 35(1), because of one simple fact: when Europeans arrived in North America, Aboriginal peoples were already here, living in communities on the land, and participating in distinctive cultures, as they had done for centuries. It is this fact ... which mandates their special legal, and now constitutional, status. ${ }^{112}$

He also emphasized that s. 35(1) has a dual purpose: to recognize and affirm existing Aboriginal rights and to reconcile those rights with the sovereignty of the Crown. ${ }^{113}$ At least in part, reconciliation requires that the Aboriginal perspective, which the Court stated it values and respects, "must be framed in terms cognizable to the Canadian legal and constitutional structure."114 Furthermore, Lamer C.J.'s "one simple fact" imposes the prerequisite that Aboriginal groups establish their prior occupancy before moving to the application of the test for the existence of an Aboriginal right. Specifically, this means that a society must demonstrate that it was well-established and socially organized — not fleeting or random. ${ }^{115}$

Before Powley, lower courts primarily constrained their deliberations of Metis Aboriginal rights by reference to the historical activities, practices, and customs of their First Nations ancestors of the Metis and by relying heavily on principles and precedents developed in the context of First Nation Aboriginal rights. A similar approach was adopted by counsel for Ontario in Powley. Drawing on the Van der Peet decision, they argued that the Powleys' right to hunt was rooted in the pre-contact practices of their Ojibway ancestors. However, the Supreme Court rejected this approach. Looking to the purpose for inclusion of the Metis in s. 35, the Court modified the principles set out in Van der Peet and developed a unique framework for addressing questions of Metis Aboriginal rights:

[T] he inclusion of the Métis in s. 35 is not traceable to their pre-contact occupation of Canadian territory. The purpose of s. 35 as it relates to the Métis is therefore different from that which relates to the Indians or the Inuit. The constitutionally significant feature of the Métis is their special status as peoples that emerged between first contact and the effective imposition of European control. The inclusion of the Métis in s. 35 represents Canada's commitment to recognize and value the distinctive Métis cultures, which grew up in areas

III For example, the Court of Appeal in Powley, supra note 2 issued a stay of its decision to facilitate consultation and negotiation on a constitutionally valid regulatory regime. See also Corbiere v. Canada (Minister of Indian and Northern Affairs), [1999] 2 S.C.R. 203, 93 C.N.L.R. 19.

$112 \quad$ Supra note 12 at 193.

$113 \quad$ Ibid.

$114 \quad$ Ibid. at 202

115 D.W. Elliot, "Fifty Dollars of Fish: A Comment on R. v. Van der Peet" (1996) 35 Alta. L. Rev. 759 at 768. See also Van der Peet, ibid. at 195-96, 204, and 208. 
not yet open to colonization, and which the framers of the Constitution Act, 1982 recognized can only survive if the Métis are protected along with other Aboriginal communities. ${ }^{116}$

In Powley, the most dramatic modification of the Van der Peet test is the Court's abandonment of the date of European contact as the appropriate time to identify the historical foundation of Metis rights. The Court also rejects the notion that Metis rights are contingent upon or derived from the practices, customs, and traditions of their First Nation ancestors, stating that such a "theory in effect would deny to Métis their full status as distinctive rightsbearing peoples whose own integral practices are entitled to constitutional protection under s. 35(1)."117 Rather, "[s]ection 35 requires that [the Courts] recognize and protect those customs and traditions that were historically important features of Métis communities prior to the time of effective European control, and that persist in the present day." $" 18$ Effective European control refers to a time when "Europeans effectively established political and legal control in a particular area." 119 The time for identifying the existence of an historical Metis community and practice, custom, or tradition grounding a contemporary Aboriginal right is "the period after a particular Métis community arose and before it came under the effective control of European laws and customs."120

Applying these principles, the Court considers whether hunting for food was an historically important feature of the Metis community at Sault St. Marie prior to effective European control of that area. The Court determines that the date of effective control roughly coincided with the signing of the Robinson Huron Treaty in 1850 and that the Metis had hunted for food prior to that date. ${ }^{121}$ However, the Court's use of the treaty should not be construed as a general rule that the correct moment in time for determining historically significant Metis practices, traditions, and customs will always coincide with the dates of the various treaties across Canada. Several factors played a role in the Court's determination, including the nature and degree of European presence in the area, the extent that colonial authorities had encouraged (or discouraged) settlement in the area, and the extent to which the Metis at Sault St. Marie were actually affected by European laws and customs. ${ }^{122}$ The debate has already begun regarding the proper indicia for determining the date of effective European control and this concept will almost certainly be a contentious point in future Metis rights litigation. ${ }^{123}$

Supra note 2 at para. 17.

Ibid. at para. 38. For a more detailed discussion of the Aboriginal ancestry theory of Metis rights and the distinctive Metis culture theory of rights adopted in this case see Bell, "Reflections on Powley," supra note 11 at 416-24 and Catherine Bell, "Metis Constitutional Rights in Section 35(1)" (1997) 36 Alta. L. Rev. 180 [Bell, "Metis"]. A modified version of the distinctive Metis culture theory is also elaborated in the Powley, supra note 2, lower court decisions of Vaillancourt and O'Neill JJ.

Supra note 2 at para. 18. See also paras. 13, 37.

Ibid. at para. 37.

Ibid.

Ibid. at paras. 39-40.

Ibid. at para. 44.

Several factors may be indicia of "effective European control," for example, the imposition of European land tenure systems, mandatory education, taxation, and/or a meaningful police presence. Dr. Frank Tough has suggested that control over a region is difficult to assert prior to the time when colonial authorities possessed accurate and reliable maps of the region in question along with a census of the population (interview of Dr. Frank Tough by co-author, Clayton Leonard). See also Bell, "Reflections on Powley," supra note 11 at 417-19. 
Acceptance of effective European control as the relevant historical period and identification of distinctive Metis communities as the source of Metis Aboriginal rights is a momentous victory for the Metis, who have consistently been denied governmental recognition as a distinct rights bearing Aboriginal people. However, the selection of different dates to measure the historical foundations of Metis, First Nation, and Inuit rights has attracted criticism from leading scholars. At a recent conference in Toronto, Brian Slattery argued that this produces a "mischievous and pernicious" result that the Supreme Court could not have intended. ${ }^{124}$ First, the difference in time between the date of contact and the date of effective European control in most of Canada spans an entire era during which significant commercial activities developed as a result of Aboriginal participation in the fur trade. Because First Nations and Inuit are still subject to the determination of their Aboriginal rights at the date of contact, they are precluded from grounding their rights in the commercial historical practices and customs that arose during the fur trade. ${ }^{125}$ Second, the date of European contact test imposes an evidentiary burden on First Nations and Inuit litigants that is not imposed on the Metis. First Nations and Inuit have only oral history and a scant written record to rely upon to establish pre-contact activities. After contact, the Metis can muster the extensive written records of the church, colonial officials, and the fur trade companies to support their assertion of Aboriginal rights. In response, one might argue that the former burden is ameliorated by the principles that a court should not seek "conclusive evidence from pre-contact times," should "interpret the evidence that exists, with a consciousness of the special nature of Aboriginal claims, and of the evidentiary difficulties in proving a right which originates in times where there were no written records," ${ }^{26}$ and should adapt the laws of evidence so that oral histories can be "accommodated and placed on an equal footing with the types of historical evidence courts are familiar with." ${ }^{127}$ However, the tendency of courts to distrust oral histories in favour of more familiar forms of evidence takes us back to Slattery's concern.

The solution, according to Slattery, is not to change the date selected in Powley, but to apply the date of effective European control to First Nations and Inuit as well. The Van der Peet test has been subject to substantial academic criticism as having no foundation in law. Slattery's solution is consistent with the purpose of s. 35 to reconcile prior Aboriginal presence with the assertion of sovereignty by the Crown and the imposition of foreign laws and customs that fundamentally altered their societies and relationships to the land. ${ }^{128}$ "As the assertion of territorial sovereignty in law is often measured based on a cumulative analysis of legislative history and historical facts, in some circumstances drawing a distinction between the date of effective assertion of sovereignty over a territory, and the date of effective control or colonization of a territory and a people, may be of little practical

Brian Slattery, "Implications of Powley for Aboriginal Peoples Generally" (Lecture presented to the Pacific Business and Law Institute Conference: Supreme Court of Canada Recognizes Métis Aboriginal Rights, November 2003) [unpublished]. This reconstruction of Dr. Slattery's argument is based solely upon Clayton Leonard's notes from his talk, therefore any errors in recounting Dr. Slattery's arguments are my own. See also Dale Gibson, "Special Sources of Métis Nation Rights," Appendix 5B to RCAP Report, supra note 20 at 320. See contra Bell, "Reflections on Powley," ibid. must be based on pre-contact activity among First Nations (see e.g. Gladstone, supra note 17). 
significance." ${ }^{129}$ In any event, the assertion of sovereignty occurs some time after first contact and, according to Slattery, French and British Colonial Governments were slow and often reluctant to extend control into new areas of Canada. ${ }^{130}$

\section{B. Metis Identity Under SECTION 35}

Powley is also a watershed decision because the Supreme Court of Canada formulates a legal test for Metis identity under s. 35. Although not intended to be a comprehensive test, the Court articulates what it considers "important components of a future definition." $|3|$ Individuals claiming s. 35 Metis rights must self-identity as Metis, have an ancestral connection to an historic Metis community, and be accepted by a contemporary community that exists in continuity with a historic rights-bearing community. Self-identification "should not be of a recent vintage." 132 "Ancestral connection" does not "require a minimum "blood quantum," but rather "some proof that the claimant's ancestors belonged to the historic Métis community by birth, adoption, or other means." ${ }^{\prime 33}$ Further, the decision of an individual ancestor to take treaty and accept Indian status does not necessarily prevent a claim. In reaching this conclusion, the lower courts emphasized that ancestors of the Powleys who took treaty and became members of the Batchewana Band continued to identify as Metis, that they were viewed by Ojibway people and government officials as a distinct people, and that a Metis community continued to live on and off reserve in the territories in question. ${ }^{134}$ Finally, as Aboriginal rights are grounded in the existence of a present and an historic community, claimants must also prove acceptance by a modern community that exists in continuity with a historic community. Acceptance in a political organization may be relevant but alone is not enough "in the absence of a contextual understanding of membership requirements of the organization and its role in the Métis community." ${ }^{135}$ The Court identifies the "core" of community acceptance as "past and ongoing participation in a shared culture, in the customs and traditions that constitute a Métis community's identity."136 Though "participation in community activities and testimony from other members" are indicia of acceptance, it is not necessary to demonstrate a "past and present mutual identification and demonstration of common belonging between the claimant and other members of the rightsbearing community." ${ }^{137}$ Thus, in Powley, evidence of membership offered by Art Bennett, a leader of the Zone 4 Metis Local that had its roots in the historic Metis community of Sault Ste. Marie, was relevant in demonstrating community acceptance.

A unique issue in Powley is whether the "lack of visibility" of an Aboriginal community at one point in history is a fatal disruption to establishing continuity with a contemporary rights-bearing community. At trial, the Crown argued that the opening of Sault Ste. Marie to

Bell, "Reflections on Powley," supra note 11 at 418 . See also the dissenting judgment of L'Heureux Dubé J., supra note 11 at 261-62, which supports Slattery's argument.

Supra note 124.

Supra note 2 at para. 30 (S.C.C.).

Ibid. at para. 31 .

Ibid. at para. 32.

See Bell, "Reflections on Powley," supra note 11 at 427-32 for a more detailed discussion of this issue and the treatment of identification criteria in the lower courts.

Supra note 2 at para. 33 (S.C.C.).

Ibid.

Ibid. 
settlement resulted in the dispersal of the Metis community and only recently did people in the area begin to identify publicly as Metis because of the formation of political and service organizations. Judge Vaillancourt held that this argument could not be sustained even if, up until the 1970 s, the community was "an invisible entity within the general population." 138 In doing so, he adopted a concept of community that is not limited to identifiable "little clusters of settlements on maps," but includes "a community of related families and individuals who are moving around a lot" and are "spread across the country for years" before they return to their "home base." 139 Thus, he took into consideration the existence of a community in the area surrounding Sault Ste. Marie. He also held that the assessment of continuity of community must take into consideration the social and political factors, including discrimination and government policy, that discouraged self-identification and undermined the stability of Metis communities.

At the Court of Appeal, Sharpe J. endorsed the spirit of flexibility adopted by the lower courts and added that the purpose of s. 35 required this approach. In his words:

\begin{abstract}
[t]he constitutional recognition of the existence of the existence of the Métis as one of Canada's Aboriginal peoples may not be capable of redressing all wrongs of the past, but it cannot be that when interpreting the constitution, a court should ignore those wrongs.... It is undeniable that past practices, including those of government, have weakened the identity of Aboriginal peoples by suppressing languages, cultures and visibility. It would be completely contrary to the spirit of $s .35$ to ignore these historical facts when interpreting the constitutional guarantee. For this reason, the continuity test should be applied with sufficient flexibility to take into account the vulnerability and historic disadvantage of the Métis. ${ }^{140}$
\end{abstract}

The Supreme Court, concurring with the findings of the trial judge, states that "lack of visibility ... does not negate the existence of a contemporary community." $|4|$ The Court also indicates that, although there must be "some degree of continuity and stability," "the 'continuity' requirement puts the focus on the continuing practices of members of the community, rather than more generally the community itself." 142

The significance of adopting the date of effective European control test, recognizing the existence of distinctive Metis communities, and of elaborating key components of Metis constitutional identity are interrelated and more fully understood with reference to previous Metis rights jurisprudence and government policy on rights recognition. In the area of resource harvesting rights, subject to a few exceptions, Metis rights have been determined based on an individual's ability to identify as Indian under the $N R T A .{ }^{143}$ Governments did not recognize Metis inherent Aboriginal rights and applied laws to the Metis in the same manner as other non-Aboriginal citizens. The judicial test for Indian identity has a history that dates

${ }_{13 \times} \quad$ Ibid. at 174 (Ont. Prov. Ct. Div.).

139) In doing so he relies on the expert testimony of Dr. Ray, reproduced in Powley, ibid. at 247 (Ont. Sup. Ct. J.).

1411 Ibid. at 332 .

$141 \quad$ Ibid. at para. 27.

$142 \quad$ Ibid. at paras. 23 and 27

143. Supra note 39. An exception is R. v. Morin (1997), 159 Sask. R. 161, [1998] 1 C.N.L.R. 182 (Sask. Q.B.); R. v. Howse, [2002] 3 C.N.L.R. 165 (B.C.S.C.), B.C.J. No. 379 (QL) and R. v. Daigle (2003), 258 N.B.R. (2d) 120, [2003] 3 C.N.L.R. 232 (N.B. Prov. Ct.), decided after the Ontario Superior Court decision in Powley adopted the inherent rights approach. 
back to at least 1894 in the Supreme Court of the North-West Territories' judgment in The Queen $v$. Howson. ${ }^{144}$ The Court was asked to determine whether a band member of mixed ancestry fit the definition of "Indian" under the Indian Act. A critical factor in the Court's deliberation was its finding that Mr. Howson lived an Indian "mode of life." 145 The emphasis on the NRTA in Metis rights litigation solidified this test with the result that accused Metis who sought to defend their hunting rights had to worry not so much about establishing their Metis identity as they did about proving that they were living an "Indian mode of life." 146 For example, in R. v. McPherson the Manitoba Provincial Court concluded that the two Metis accused had a right to hunt because they "lived mostly off the land," "were very, very poor and often went hungry," "spoke Cree," and as children had "lived in the same way as the treaty kids." 147 In Ferguson, the Provincial Court of Alberta evaluated the "cultural authenticity" of the accused and concluded he met the "Indian mode of life" test because he had "[grown] up in an isolated community in northern Alberta" and was "one-half Indian racially." 148 This approach was subsequently endorsed on appeal as being consistent with the rational of para. 12 of the $N R T A$, which was intended to protect a lifestyle that was dominant when the transfer of natural resources to the Province occurred. ${ }^{149}$

Academic commentary on the application of the "Indian mode of life test" to Metis has been critical. Chris Andersen, a professor of Native Studies at the University of Alberta, has suggested that "[j] udges hold stereotypical views about what it means to live a 'traditional' lifestyle, stereotypes that Indians themselves are not required to live up to."150 Moreover, even in the rare instances when the courts have looked beyond "Indianness" to consider Metis culture and history, they have tended to suffer from "Red River myopia" and are unable to see the diverse history of the Metis throughout Canada. ${ }^{|5|}$ Consequently, the judiciary has been operating on a "binary opposition," expecting the Metis to justify their hunting right by proving their "Indianness" or rejecting assertions of an Aboriginal right because the Metis accused in question is not Indian enough. ${ }^{152}$ Failing to adequately consider the unique identity, culture, history, and political institutions of the Metis in developing a theory of inherent Metis rights independent of the NRTA had promoted the "judicial assimilation of ... rights-bearing Metis collectivities with Indian, Inuit and European ancestral populations." 153 The result was simply a "different manifestation of an old federal policy." 154 The new emphasis on self-identification, connection to a distinctive historic Metis community, and acceptance by a contemporary Metis community respects the unique history

(1893), 1 Terr. L.R. 492.

Ibid. at 494.

For more a more critical analysis of judicial' conceptions of "Indianness," see Chris Andersen, "The Formalization of Métis Identities in Canadian Provincial Courts" in Ron F. Laliberte et al., eds., Expressions in Canadian Native Studies (Saskatoon: University of Saskatchewan Extension Press, 2000) 95 at 105.

McPherson, supra note 39 at 147.

Ferguson, supra note 39 at 99, 107 (Alta. Q.B.), 152 (Alta. Prov. Ct.).

Ibid. (Alta. Q.B.).

Supra note 146 at 111.

Ibid. at 101.

Ibid. at 97.

Bell, "Metis," supra note 117 at 182.

lbid. at 183. 
and character of Metis peoples as well as the right of the community to determine its own membership. ${ }^{155}$

The identity test in Powley also generates new challenges for contemporary Metis organizations seeking to enter negotiations relating to s. 35 Metis rights. Before presenting key components of Metis identity, the Supreme Court emphasizes the importance of developing standardized membership criteria so that "legitimate rights-holders can be identified." 156 Immediately after setting out the identity test, the Court comments:

[i]t is important to remember that, no matter how a contemporary community defines membership, only those members with a demonstrable ancestral connection to the historic community can claim a s. 35 right. Verifying membership is crucial, since individuals are only entitled to exercise Métis Aboriginal rights by virtue of their ancestral connection to and current membership in a Métis community. ${ }^{157}$

As connection of a claimant's ancestor to an historic community can be established by "birth, adoption or other means," by analogy, and by drawing on the logic employed by the Court in assessing the existence of identifiable communities, recognition of membership in contemporary communities (and therefore entitlement to share in the exercise of their collective Metis Aboriginal rights) should also include association by "adoption or other means." 158 The statement that the "core" of community acceptance is "past and ongoing participation in a shared culture" and "customs and traditions that constitute a Métis community's identity" also supports this conclusion. ${ }^{159}$ Nevertheless, reviewing membership criteria to determine compliance with Powley in preparations for negotiation or litigation may be difficult, time consuming, and costly for many contemporary organizations.

Challenges may be less pronounced for the Métis National Council (MNC) and its provincial affiliates who, after constitutional recognition of Metis Aboriginal rights in 1982, developed clear membership criteria that emphasized connection to the Red River Metis community in Manitoba and included other self-identifying Metis involved in the scrip distribution system. ${ }^{160}$ At a 2002 national convention, the MNC revised its membership

For an example of these criteria being used to deny Metis constitutional identity see $R$. $v$. Castonguay (2002), 257 N.B.R. (2d) 67, [2003] 1 C.N.L.R. 177 (N.B. Prov. Ct.).

Supra note 2 at para. 29.

Ibid. at para. 34.

Ibid. at para. 32.

Supra note 2 at para. 33.

In the 1984 conferences on Aboriginal constitutional reform, the MNC proposed an amendment to the Canadian Constitution that would define Metis in s. 35 as those who are descendants of Metis who received or were entitled to receive scrip or land grants under the Manitoba Act, 1870, S.C. 1870 , c. 3 or under the Dominion Lands Act, 1879, supra note 98. Eight years later in 1992, the Métis Nation Accord, reproduced in RCAP Report, supra note 20 at 376-82 was put forward as part of the Charlottetown Accord amendments. It defines the Métis Nation as a community of individuals who are descendants of Aboriginal people who self-identify as Metis, who are distinct from Indian and Inuit, and who "were entitled to receive land grants and/or scrip" under the Manitoba Act, 1870 or the Dominion Lands Act, 1879 (ibid.). This Accord was intended to be signed by the MNC, the governments of Canada, Ontario, Manitoba, Alberta, Saskatchewan, British Columbia, and MNC affiliates in each of these provinces. As the Charlottetown Accord ultimately failed, the Métis Nation Accord was never signed. It also had provisions for negotiating self-government, financing enumeration, and a registry system for the Metis. It did not apply to Metis under the Alberta Metis settlements legislation. Most recently at a conference in Toronto, Jason Madden, legal counsel for the MNC, 
criteria to reflect more clearly the identity test in Powley. ${ }^{161}$ This definition no longer contains a reference to the scrip system as a core component of Metis identity, but it continues to emphasize connection to a defined territory and Metis community. A Metis person is defined as "a person who self-identifies as Métis, is of historic Métis Ancestry, is distinct from other Aboriginal peoples and is accepted by the Métis Nation." 162 The historic Métis Nation is defined as those "Aboriginal people then known as Métis or Half-Breeds" who resided in the "'Historic Métis Nation Homeland' ... in west central North America used and occupied as [their] traditional territory." ${ }^{163}$ However, for a variety of social, legal, and political reasons, Metis and non-status people have over the course of history joined together to have a more effective voice and the MNC membership criteria have not always been strictly applied. ${ }^{164}$ Thus, it is possible that some provincial affiliates have within their membership individuals without ancestral connections to historically distinctive Metis communities. Their connection may have to be established by some "other means" or they may be excluded from the benefit of policies designed to address rights of the Metis. As a practical matter, for negotiation purposes, federal and provincial governments may not require demonstrable proof that all members of an organization meet the ancestral connection test in the face of some clear membership criteria requiring the same, so long as they are satisfied that the vast majority are legitimate rights-holders through some means and the rights of other Aboriginal groups are not adversely affected.

Complying with the Supreme Court's direction on membership may pose greater challenges for Metis political institutions and communities that do not require an ancestral connection to an historical Metis community as a criterion for membership. Does Powley require them to revise their membership criteria or isolate those who have a demonstrable connection to an historic Metis community from those who do not for the purpose of asserting s. 35 Metis right? Consider, for example, the Metis settlement scheme in Alberta. There are eight settlements in Alberta covering approximately 1.2 million acres of land protected, administered, and governed in accordance with provincial legislation that includes a statutory definition of Metis. The Settlements have their own regional government known as the Metis Settlements General Council that represents them in provincial and federal negotiations. They were initially created as farming colonies in the $1930 \mathrm{~s}$ in response to the destitute circumstances of "mixed white and Indian blood" populations other than "Indian

forcefully put forward the position that there is only one Metis people in Canada and that they constitute the entirety of Métis Nation of Canada which spans from Sault Ste. Marie through the prairie provinces and into a small corner of Northern BC, see Jason Madden, "Identifying Metis Rights Holders" (Lecture presented to the Pacific Business and Law Institute Conference: Supreme Court of Canada Recognizes Métis Aboriginal Rights, November 2003) [unpublished]).

16.1 "Resolutions of the Métis National Council's 18th Annual General Assembly, Westin Edmonton Hotel Edmonton, AB, September 27th and 28th, 2002" online: Métis National Council, (January 9, 2004) $<$ www.metisnation.ca/DEFINITION/home.html>.

Ibid.

Ibid.

For a discussion of the many historical and political factors that have contributed to the issues around Metis identification and the evolution of membership criteria in provincial Metis organizations, see e.g. Sawchuk, Sawchuk \& Ferguson, supra note 34; McMahon \& Martin, supra note 72 at 290-97; Gokias, "Domestic Recognition in the United States and Canada" in Chartrand, supra note 72 at 148-68; Catherine Bell, "Who are the Metis People in Section 35(2)?" (1991) 29 Alta. L. Rev. 351; RCAP Report, supra note 20 at 199-208; Gibson, "When is a Métis an Indian?" supra note 72; and Bell, "Reflections on Powley," supra note 11 at 424-33 
or ... non-treaty Indians" as defined by the Indian Act. ${ }^{165}$ The current definition of a Metis person under the Metis Settlements Act is "a person of aboriginal ancestry who identifies with Metis history and culture" and membership criteria are broad enough to include some members who are of Aboriginal ancestry but are not necessarily descended from a distinctive historic Metis community. ${ }^{166}$ Although persons registered under the Indian Act can only obtain settlement membership under exceptional circumstances, there are individuals who are Metis under the Metis Settlements Act, self-identify as Metis, and who have status as Indians under the Indian Act. ${ }^{167}$

There are some people on the Metis settlements and members of other Metis organizations whose ancestors took treaty and had Indian status at one time or another and who are now entitled to be reinstated as status Indians under amendments made to the Indian Act in 1985 . Metis settlements legislation only excludes from membership those actually registered as Indians. Those entitled fall within the statutory definition of an Indian and a Metis; but, according to Powley, this does not necessarily disentitle them from being Metis. ${ }^{168}$ The fact that Steve Powley's grandmother and her predecessors lived on an Indian reserve for "a period of time" (and that his great uncle was a signatory to the Robinson-Huron Treaty in 1850) did not "negate the Powleys' Métis identity." ${ }^{169}$ Rather, "the individual decision by a Métis person's ancestors to take treaty benefits does not necessarily extinguish that person's claim to Métis rights. It will depend ... whether there was a collective adhesion by the Métis community to the treaty." 170 If having an ancestral connection to a Treaty First Nation does not negate an individual's Metis identity, it may be possible for a person who has an ancestral connection to a Treaty First Nation and who possesses Indian status to claim both legal identities. There is some analogy here to a person who holds both Canadian and American citizenship. He or she may have chosen to identify primarily as Canadian and to live in this country. This does not negate the right to travel on an American passport, move to the United States, or exercise other rights associated with being American. However, a person cannot travel on both passports at the same time; he or she must choose from one trip to another. Similarly, it may be that a Metis person can choose which "passport" he or she is using depending on what right is being exercised and where. However, federal and provincial

Metis Population Betterment Act, later called the Metis Betterment Act, S.A. 1938, c. 6, s. 2(a). The Indian Act of the time excluded half-breeds with scrip history and a non-treaty Indian included any person of "Indian blood" who lived an "Indian mode of life." However, mixed bloods who would fit this definition by virtue of their sustenance lifestyle joined the settlements and blended these traditions with the agricultural requirements of settlement life (Indian Act. R.S.C. 1927, c. 98, s. 2). See Bell, Settlements Legislation, supra note 21 at 4-5; and Bell \& MSAT, supra note 34 at 7-20 for a more detailed history of the people occupying and the selection of settlement lands based on historical Metis connection.

Metis Settlements Act, supra note 21, ss. 1(j), 74, 75.

A person registered as an Indian is not eligible to apply for membership unless "registered as an Indian or an Inuk when less than 18 years old ... lived a substantial part of his or her childhood in the settlement area," had a parent who was a settlement member, and membership is approved by a settlement by-law (ibid., s. 75). Further, settlement members without scrip history in their background have qualified for reinstatement to Indian Status under 1985 amendments to the Indian Act and litigation is pending their ability to retain dual status.

Indian Act, supra note 29, s. 2 defines an Indian as a person who is "registered as an Indian or is entitled to be registered as an Indian" [emphasis added].

Powley, supra note 2 at para. 5 (S.C.C.).

Ibid. 
governments will likely resist this conclusion and require individuals that are legitimate rights-holders in either community to make a choice.

Given these complications and uncertainties, local Metis settlement governments and the General Council may have to convince federal and provincial governments to include all of their members in the benefits of negotiations concerning s. 35 Metis rights. The vast majority of members are descendants of distinctive historic Metis communities - those that are not identified as Metis and that acquired Metis status through Alberta's Metis settlements legislation or a history of family connections dating to the creation of the original Metis colonies in the 1930s. In addition, pragmatic, personal, and economic consequences arise when attempting to distinguish between Metis bearing constitutional rights and other Metis for existing government relations, consultation mechanisms, and life within the settlement communities. It is difficult to conceive that a court would disentitle settlement members who identify as Metis, are legally recognized as such, and have been accepted by an established Metis community with a clearly defined territory and readily identifiable representative government. It may well be that this is the type of situation the Supreme Court has in mind when it suggests that proof of ancestral connection can be by birth, adoption, or "other means."

Jean Teillet, counsel for the Powleys, asserts that it is "going to be very difficult for organizations like CAP [Congress of Aboriginal Peoples] who have always said that anybody who had any Aboriginal ancestry could claim to be Métis and could claim rights." 172 Some affiliates of CAP who identify as Metis and who trace their origins to historic Metis communities may need to negotiate rights on their own behalf given CAP's diverse and inclusive membership. CAP, if it has not done so already, may have to develop categories of membership that distinguish between its Metis, non-status, and status non-reserve constituencies for the purpose of identifying those who can assert Metis Aboriginal rights.

It is important to note that First Nations and Inuit do not have to meet similar objective measures of individual and group identity when asserting s. 35 claims. Slattery suggests that this test, as it applies to the Metis, is problematic for two reasons. ${ }^{173}$ First, the language of s. 35 does not support the application of different identity tests for Metis, Indians, and Inuit. The guarantee of existing Aboriginal rights in s. 35(1) applies to all "Aboriginal" people and does not differentiate among them. This is not to say that all Aboriginal cultures are the same, but that the guarantee under s. 35(1) is the same. Further, s. 35(2) provides that "aboriginal peoples of Canada' includes the Indian, Inuit and Métis." 174 Use of the word "includes" means that this section does not provide an exhaustive list of Aboriginal peoples. These observations suggest that the only identity issue that should be faced by a people or an individual claimant under s. 35 is proof of Aboriginal ancestry - it is not necessary for claimants to prove that they are Indian, Inuit, or Metis in particular. Finally, nothing in s.

172 Paul Barnsley, "Monumental Win for Metis: Powley determines who can access Section 35 rights" Windspeaker 21:7 (October 2003) 8 at 8.

173 Supra note 124.

17. Constitution Act, 1982, supra note 3. 
35(2) suggests that the three categories are mutually exclusive. An Aboriginal group need not be exclusively Metis, Indian, or Inuit. These categories can be "overlapping descriptions." 175

Second, in Slattery's opinion, Powley stands for the general proposition that a Metis community is defined as a group of mixed bloods, who develop their own distinctive customs and practices, resulting in a distinctive identity as a community or people. ${ }^{176}$ All Aboriginal cultures today are a genetic and cultural fusion of two worlds coming together during the period from first contact to effective European control. Therefore, like the Metis, nearly all Aboriginal people in Canada today are post-contact, mixed-blood, mixed-culture peoples and are capable of falling within the judicial conception of a Metis community. On these grounds, the distinction between Metis and some, or most, other Indian communities fails. In the minds of the authors, what this point underscores is how self-determination through individual and group self-identification is pivotal in understanding Aboriginal constitutional identity. The solution proposed by Slattery is not to eliminate the Metis identity test, but to modify it and to apply it uniformly. He argues that what is required is for the Supreme Court of Canada to take the next necessary step and replace the word "Metis" in the identity test with "Aboriginal." The identity test thus becomes 1) self-identification as Aboriginal; 2) an ancestral connection to an historic Aboriginal community; and 3) acceptance by a contemporary Aboriginal community.

\section{LoOking Beyond Powley: Preliminary Thoughts on METIS COMMERCIAL HARVESTING RIGHTS IN ALBERTA}

Does Powley support the assertion of commercial Metis Aboriginal rights to hunt in Alberta? It is important to remember that Powley was concerned with the rights to hunt for food of members of the Metis community in Sault Ste. Marie. The decision does not affirm any commercial Metis harvesting rights. However, when Powley and Blais are read together, it is possible to construct an argument as to why Metis, particularly those who trace their ancestry to Metis populations who participated in the fur trade, have commercial rights to hunt, fish, and trap.

Section 35 requires that courts "recognize and protect those customs and traditions that were historically important features of Métis communities prior to the time of effective European control, and that persist in the present day." "I77 In a commercial hunting rights claim, the pivotal question is whether hunting for exchange and participating in a trade economy was an integral feature of the historical Metis community prior to effective European control. Existing case law supports the proposition that if an Aboriginal community engaged in trade beyond that which is incidental to social and ceremonial activities at the relevant historical date, this activity can ground the existence of a contemporary commercial Aboriginal right or at least a right to hunt for a moderate livelihood, even if this practice is now substantially curtailed by legislation. ${ }^{178}$ The reader will recall that the Supreme Court

175 Slattery, supra note 124.

176 Ibid.

177 Powley, supra note 2 at para. 18 (S.C.C.)

178 Following this reasoning, the Supreme Court recognized in Gladstone, supra note 17 at 78 that the Heiltsuk had an Aboriginal right to sell herring spawn on kelp. However, they subsequently held that limitations on the exercise of this right were justified. The concept of moderate livelihood is probably 
has accepted as the date for ascertaining the historic foundations of Metis rights the date of effective European control. In Powley, the date selected was 1850, the year that the Robinson-Huron Treaty was signed. ${ }^{179}$ Arguably, this means that the dates of effective control for Metis in Alberta could correspond with the signing of the numbered treaties in this province. ${ }^{180}$ However, it is at least possible that for some portions of Alberta another possible date is the Northwest Resistance of 1885, which could be viewed as the effective date of imposing European laws and customs on those Metis communities that participated in the conflict and that trace their ancestry to the Red River. ${ }^{181}$

It is not our intention here to present the depth and volume of evidence required to substantiate the commercial rights to hunt of a particular Metis community in Alberta at the date of effective control. However, Metis history contains considerable evidence in support of the argument that Metis hunted, fished, trapped, and gathered for commercial purposes. The records of Hudson's Bay Company posts bear testimony to the crucial importance and sheer volume of provisions that Metis provided on an annual basis. ${ }^{182}$ Furthermore, the records of the Government of Canada also contain important evidence that commercial hunting, fishing, and trapping were "central and significant" features of historical Metis culture in Alberta before the signing of Treaties 6 and 8, which cover many of the regions in which historic Metis populations are found ${ }^{183}$ It is also well established in secondary sources that the Metis were renowned as commercial trappers, fisherman, fur traders, and hunters. ${ }^{184}$ Academic opinion supports the conclusion that the traditional activities and customs of the Metis centered heavily on hunting, trapping, and fishing for commercial purposes. ${ }^{185}$

Is there adequate continuity between the contemporary Metis communities and historic Metis communities in Alberta to provide the legal foundation for asserting commercial

best understood as the right to sustain oneself and one's family. The extent of recognition of the nonsustenance-based right could vary with the extent of trade established on the facts of a particular case. For a discussion of the concept of "moderate livelihood" in the treaty context, see $R$. v. Marshall, [1999] 3 S.C.R. 456, (1999), 177 D.L.R. (4th) 513.

Supra note 2 at para. 40 (S.C.C.).

The numbered Treaties that cover Alberta were made as follows: Treaty 4 in 1874, Treaty 6 in 1876, Treaty 7 in 1877, Treaty 8 in 1899 and Treaty 10 in 1906 (see online: Indian and Northern Affairs Canada <www.ainc-inac.gc.ca/pr/trts/hti/site/maindex_e.html >).

Treaty 8 covers most of northern Alberta where most, but not all, Metis communities in Alberta reside. See also Powley, supra note 2 at para. 37 (S.C.C.): "This pre-control test enables us to enables us to identify those practices, customs, and traditions that predate the imposition of European laws and customs on the Métis."

For an example of the wealth of information in trading post records, see Frank Tough, As Their Natural Resources Fail: Native Peoples and the Economic History of Northern Manitoba, 1870-1930 (Vancouver: University of British Columbia Press, 1996).

For example, in his annual report to the federal Department of Marine and Fisheries in 1894, Fisheries Inspector Gilchrist noted that the Metis at Pigeon Lake, through their fishing activities, were able to "earn a very fair livelihood by working at it systematically and with intelligence" (Canada, "Report of the Federal Department of Fisheries" by Gilchrist in Sessional Papers, No. 11 A (1894) at 347).

Sawchuk, Sawchuk, \& Ferguson, supra note 34 at 18-20; RCAP Report, supra note 20 at 199-200, cited in Powley, supra note 2 at para. 10 (S.C.C.).

See Arthur J. Ray, Indians in the Fur Trade: their role as hunters, trappers, and middlemen in the lands southwest of Hudons Bay, 1660-1870 (Toronto: University of Toronto Press, 1974); and Gerhard J. Ens, Homeland to Hinterland: The Changing Worlds of the Red River Metis in the Nineteenth Century (Toronto: University of Toronto Press, 1996). 
hunting rights? ${ }^{180}$ The reader will recall that the Court found that a Metis community had "persisted in and around Sault Ste. Marie" despite the fact that "to a large extent [it was] an "invisible entity' from the mid-19th century to the 1970s." 187 It is difficult to make general statements concerning all Metis communities in Alberta. Rather, assessing continuity is an exercise that is driven by historical and contemporary facts specific to a particular Metis community alleged to be the source of an Aboriginal right. However, there is little doubt that communities such as the Metis settlements are contemporary Metis communities and fall within the definition of "a group of Métis with a distinctive collective identity, living together in the same geographic area and sharing a common way of life." 188 Further, as discussed earlier, the settlement population is composed primarily of descendants of people who historically identified as a Metis community and for whom the scrip distribution system had failed. ${ }^{189}$ Although it is possible that recognition of Metis rights will be limited to those members only, the challenge for the settlements is not so much in providing proof of continuity as in the identification of traditional territories. Settlement lands were not set aside until after 1938, well after the signing of the treaties in Alberta. Although some lands were selected on the basis that Metis communities were established in those areas, other factors came into play, such as the availability of fish and the suitability of land for agricultural development. Thus, traditional territories over which commercial hunting, trapping, and fishing rights were exercised may not coincide with, or may extend beyond, settlement areas. $^{190}$ Indeed, these areas may overlap with traditional territories of other Metis organizations in Alberta who represent communities that meet the Powley test, such as the Métis Nation of Alberta, and those whose members trace Metis ancestry to the same geographical areas.

If Alberta Metis have an Aboriginal right to hunt commercially or for a moderate livelihood, has this right been extinguished? The Court in Powley states that only the federal government can extinguish Metis Aboriginal rights. The federal government has not legislated in this area. The fact that individual Metis took treaty is not evidence of extinguishment and Metis in Alberta did not collectively adhere to treaty. Furthermore, in northern Alberta adherence to Treaty 8 would be evidence of an historical commercial right. However, the Supreme Court has ruled that commercial hunting rights under Treaty 8 have been extinguished by a modification to Treaty 8 contained in para. 12 of the NRTA ${ }^{191}$ Even

Powley, supra note 2 at paras. 23-24, 27, and 33 (S.C.C.).

Ibid. at para. 24 [footnotes omitted].

Ibid. at para. 12

For more information on the improprieties of the scrip process, see Linda Goyette, "The X Files" (March/April 2003) 123 Canadian Geographic at 70-78 and 80; and Frank Tough \& Leah Dorion,

"'The claims of the Half-breeds ... have been finally closed': A Study of Treaty Ten and Treaty Five Adhesion Scrip," Research Study (Ottawa: RCAP, 1993). Two cases regarding the validity of the scrip process are currently before the Courts: Morin v. Canada \& Saskatchewan (Q.B. File No. 619-1994, commenced March 1, 1994), which deals with scrip distributed under the Dominion Lands Act, 1879, supra note 98 in Northwest Saskatchewan and Dumont v. Canada (A.G.), [1990] I S.C.R. 279, 2 C.N.L.R. 19, rev'g (sub nom Manitoba Metis Federation Inc. v. Canada (A.G.)), [1988] 3 C.N.L.R. 39 (Man. C.A.), rev'g (1987) 48 Man. R. (2d) 4, [1987] 2 C.N.L.R. 85 (Q.B.). See also Dumont v. Canada (A.G.) (1991), 75 Man. R. (2d) 273, [1992] 2 C.N.L.R. 34 (C.A.), rev'g (1990) 71 Man. R. (2d) 199, [1991] 3 C.N.L.R. 22 (Q.B.). See also Manitoba Métis Foundation Inc. v. Canada (A.G.), [2002] M.J. No. 57, which addresses scrip distributed under the Manitoba Act. 1870, supra note 160. Bell \& MSAT, supra note 34 at 7-8 and 19-20.

Badger, supra note 103. 
if scrip is considered an effective extinguishment of Metis title, a highly contentious proposition currently being litigated, this does not automatically lead to the conclusion that hunting rights were extinguished absent clear and plain intent to the contrary. ${ }^{192}$ Such intent is not evident in the language of legislative provisions authorizing the issuance of scrip, the scrip documents themselves, or the litany of orders-in-council generated by the scrip process. ${ }^{193}$

For these reasons, the continuity of Metis commercial hunting rights in Alberta may depend upon the issue of whether para. 12 of the NRTA applies to the Metis. As mentioned above, in the Prairie Provinces the NRTAs have loomed large in Metis hunting rights jurisprudence until the decision in Blais. In Ferguson, the leading case in Alberta, Mr. Ferguson was charged with hunting without a license and with unlawful possession of wildlife under the Alberta Wildlife Act. ${ }^{194}$ The Court found that Mr. Ferguson was a "nonTreaty Indian" because he followed "the Indian mode of life" and therefore was within the definition of an Indian under the NRTA. ${ }^{195}$ Although the Court of Queen's Bench affirmed this decision, it expressed concern that Mr. Ferguson's "Indian mode of life" was somehow diminished in the eyes of the provincial court judge by the fact that he made his living by "running tractors and building roads." " Even a "casual or intermittent [Indian] lifestyle" met the necessary criteria for protecting Ferguson's "Indian" hunting right under para. 12 of the NRTA.${ }^{197}$ Decided before in Blais and Powley, the Court rejected the argument of defence counsel that Mr. Ferguson's Metis hunting right was "recognized and affirmed" by s. 35(1) of the Constitution Act, 1982. If Ferguson continues to hold true, any Aboriginal right to hunt, other than for food, enjoyed historically by the Metis, is likely extinguished. The Supreme Court consistently has confirmed that para. 12 of the NRTA extinguished the right of Indians to hunt commercially in exchange for protecting their right to hunt for food over

The trial judge in Blais, supra note 5 at 130, 144-145, concluded that the allotment of scrip had extinguished Metis "Indian title," other Metis Aboriginal rights were "bundled" with title and consequently, Metis Aboriginal rights had been extinguished. The Manitoba Court of Appeal, supra note 5 at para. 15 held that the trial judge erred in reaching this conclusion, as the Supreme Court of Canada clearly established in Adams, supra note 36, that Aboriginal rights are not tied to Aboriginal title. It is also worth noting that the Supreme Court in Blais, supra note 5 at para. 34 remarked that "the history of scrip speculation and devaluation is a sorry chapter in our nation's history." There is also significant academic opinion supporting the position that scrip did not effectively extinguish title (see e.g. RCAP Report, supra note 20; Paul Chartrand, Manitoba's Métis Settlement Scheme of 1870 (Saskatoon: Native Law Centre, University of Saskatchewan, 1991); and Donald Sprague, "Government Lawlessness in the Administration of Manitoba Land Claims, 1870-1887" (1980) 10 Man. L.J. 416). The question of whether scrip validly extinguished Metis Aboriginal title is currently before the Courts (see Morin and Dumont, supra note 189).

See Manitoba Act, 1870, supra note 160, s. 31 and Dominion Lands Act, 1879, supra note 98, s. 125(e), which provided for the extinguishment of Half-breed "Indian title" through the distribution of scrip. The federal cabinet approved at total of 157 Orders-in-Council under the Manitoba Act and the Dominion Lands Act for the purpose of defining eligibility criteria for Metis scrip and to address other issues related to Metis land grants; none of these orders in council address the extinguishment of Metis Aboriginal rights, see Kevin MacLennan, "For the Purposes of the Dominion": Métis Entitlement and the Regulatory Regime of "Halfbreed" Scrip (Honours Thesis, University of Alberta, School of Native Studies, May 2002) [unpublished, archived at School of Native Studies Library, University of Alberta]. Supra note 39.

Ibid. at 152 (Prov. Ct.). The same "Indian mode of life" test has been applied in Saskatchewan and Manitoba Metis hunting rights jurisprudence, see Laprise, Grumbo, and McPherson, supra note 39. 
an expanded territory - specifically, on all unoccupied Crown lands within the Prairie Provinces. ${ }^{198}$ The Province would be entitled to regulate Metis hunting subject to their right to hunt for food in all seasons on unoccupied Crown lands and on other lands to which they may have a right of access.

Blais may represent a new starting point for answering the question of whether the Metis have Aboriginal rights to hunt for commercial purposes in Alberta. Assuming Blais applies, this presents two significant benefits for the Metis. First, because the Metis are not "Indians" for the purpose of the $N R T A$, the jurisprudence relating to the hunting rights of Indians under the NRTA will not to apply to the rights of the Metis. Thus, the NRTA cannot be viewed as an extinguishment of Metis commercial rights and, absent other federal legislation of clear and plain intent, this right is protected in s. 35 in its unregulated form. Second, if Alberta Metis are not "Indians" under the NRTA, then the awkward and stereotypical "Indian mode of life" test applied by Alberta and Saskatchewan courts in pre-Blais Metis hunting rights jurisprudence is no longer the appropriate starting point for determining issues of Metis hunting rights. The appropriate beginning is to ask whether commercial hunting was an integral feature of an historical distinctive Metis community. If we accept that Metis hunting goes to the core of Indianness under federal jurisdiction and that the doctrine of interjurisdictional immunity applies, a provincial government may be exceeding its jurisdiction in regulating this right. However, the creation of a legislative vacuum, practical ramifications for peaceful relations with other citizens of the Province by the specter of unlimited rights to hunt and exploit animals, and public safety and conservation concerns would all be sound reasons for a court to stay its decision until valid laws are in place or to seek a creative constitutional solution consistent with the purpose of s. 35 .

Compliance with s. 35 means that if a commercial right is established and the Province has jurisdiction, the Province must have a valid legislative objective for limiting the exercise of this right and must act in a manner consistent with its fiduciary obligation to the Metis. Given the many valid reasons to regulate hunting, the practical significance of the s. 35 guarantee is scrutiny of provincial compliance with its fiduciary obligation. At the very least, this entails a duty to consult the Metis on restrictions of their hunting rights and to enter into discussions "in good faith, and with the intention of substantially addressing" Metis concerns. ${ }^{199}$ Other factors that will be considered are whether there is "as little infringement as possible" to effect the legislative objective and, if the right is expropriated, whether "fair compensation" is available. ${ }^{200}$ Applying these factors to a commercial right to fish in Gladstone, the Supreme Court also held that the size of an Aboriginal community in relation to the rest of the population, importance of the fishing to the group economy, historical reliance on the resource in issue by non-Aboriginal groups, and economic and regional fairness are all relevant factors in ascertaining what is a justifiable accommodation. ${ }^{201}$ Powley stands for the further proposition that Metis rights are to be accommodated in a manner

1\%x See Frank, supra note 103 at 100; Moosehunter, supra note 103 at 285: Horseman, supra notc 103 at 931-32; and Badger, supra note 103 at para. 35.

(י) Delgamuukw, supra note 14 at 79.

$201 \quad$ Sparrow, supra note 8 at 187.

201 Supra note 17. 
analogous to those of First Nations and that justifications to limit hunting rights must be species-specific. $^{202}$

In Alberta, a fundamental question will be whether the negotiation of hunting rights contained in Metis settlements legislation and the assumption of limited jurisdiction over hunting on settlement lands by Metis settlement governments satisfys the fiduciary obligation of the province. As a general rule, the by-laws of local Metis settlement governments and the policies enacted by the General Council, with which all settlement by-laws must comply, must be consistent with the Metis Settlements Act and other provincial law. ${ }^{203}$ Given the importance of hunting, fishing, trapping and gathering to the Metis, the General Council policies in these areas are given priority over the $A c t$ and other provincial law, but they must be approved by all eight settlements and the Lieutenant Governor in Council. Further, in order to protect rare or endangered species, the Lieutenant Governor in Council may repeal his or her approval. ${ }^{204}$ Pursuant to this power the General Council can control who has access to hunting rights on settlement lands, prescribe the process for acquiring these rights, and determine the terms and conditions under which they can be exercised. However, rights to hunt under the existing policy are confined to hunting for food on settlement land, with control over allocation of permits and other restrictions consistent with the provincial game laws now in the hands of settlement governments. ${ }^{205}$ In contrast, the Metis Settlements Act does address commercial fishing rights. It provides that a Settlement Council may, with the permission of the Minister, issue commercial fishing licenses to settlement members and to members of adjacent settlements to fish in the settlement area or in waters adjoining those areas. In that event, a total proportion of the catch designated by the Minister must be made available only to settlement members. ${ }^{206}$ The accommodation of this right is not surprising given the original purpose of the legislation to promote agriculture and commercial fishing to sustain the destitute "half-breed" population at the time that settlement lands were first set aside. Whether these accommodations are sufficient in the face of an established Aboriginal right is a question that only can be answered by taking into consideration the factors enunciated above.

Alberta may argue that it has satisfied its duty to consult on hunting rights not just with settlement members, but with all Metis in Alberta because the definition of Metis for the purpose of acquiring hunting rights as settlement members is broad enough to include them. This proposition - surely one that will attract strong opposition from the Métis Nation of Alberta - is difficult to maintain in light of the limited amount of land available for hunting if all persons entitled to registration became settlement members; membership in the Métis Nation of Alberta of many Metis who may be from communities that the original settlement scheme was intended to assist, but who never affiliated politically or culturally with the

Supra note 2 at para. 50 (S.C.C.).

Supra note 21 at ss. 72, 227,230. Section 72 of the Metis Settlements Act prohibits settlement policies and bylaws from contravening provincial statutes expect where hunting, fishing, trapping and gathering are concerned. General Council is composed of representatives from all eight settlement councils and has the ability to enact judicially enforceable policies related to the collective interests of the settlements. Areas of jurisdiction are articulated in ibid., ss. 222-23.

Ibid., ss. 72(1), 226.

Metis Settlements General Council Hunting, Fishing, Trapping, and Gathering Policy (General Council Policy No. 90001) O.C. 642/90, A. Gaz. 1991.I.1721.

Metis Settlements Act, supra note 21, ss. 130-33. 
settlement population; and the failure to enter discussions with the intent of substantially addressing the impact of settlement legislation on Aboriginal rights with representatives of all Metis in the Province. We emphasize again that the Constitution of Alberta Amendment Act clearly states that the legislation is not intended to "abrogate or derogate form any Aboriginal rights referred to in section 35 of the Constitution Act, 1982."207 It is impossible to argue that Aboriginal rights were considered and that relevant factors weighed when they were expressly excluded from discussion in the negotiation process. Many of these same arguments apply to an assessment of whether there was sufficient consultation with the settlement populations themselves. This is so despite the fact that negotiations for this legislation occurred over a period of at least ten years, rigid time lines were avoided, and funding was provided to ensure that the legislation would effectively settle litigation over natural resource revenues under settlement lands. ${ }^{208}$

\section{CONCLUSION}

Powley and Blais are as significant for the questions that they raise as for the questions that they settle. In Van der Peet, Lamer C.J. emphasized that the doctrine of Aboriginal rights, now enshrined in the Constitution, exists because of "one simple fact": Aboriginal peoples "were already here, living in communities on the land, and participating in distinctive cultures, as they had done for centuries." 209 Powley confirms that the "one simple fact" also holds true for the Metis: they are an Aboriginal people who have lived in communities on the land and who developed their own distinctive practices, customs, and traditions before the effective imposition of European sovereignty. The fact that Metis have successfully resisted efforts to fold into Euro-Canadian or First Nations societies is prima facie evidence that they are distinct peoples with an awareness of, and a continuity with, their past.

Now that Powley and Blais have provided a framework for addressing Metis Aboriginal rights, efforts should turn to negotiating a fair and equitable place for the Metis in the Canadian federation. In Van der Peet, the Court stated that the purpose of s. 35 is "the reconciliation of the pre-existence of Aboriginal societies with the sovereignty of the Crown. ${ }^{210}$ For the Metis, Powley is the first step toward fulfilling the purpose of s. 35 . The first measure of progress will be the willingness of the Crown to restore and uphold its honour by entering into good faith negotiations with the Metis in order to reach agreement on identifying bone fide Metis rights-holders. Efforts can then turn to the broader questions raised by Powley and Blais. What is the nature, scope, and content of Metis Aboriginal rights throughout Canada? How do Metis rights differ from one community or region to another? Has Metis Aboriginal title been extinguished through the distribution of scrip? What level of government is responsible for the Metis? Because of Powley, it is clear that these questions are no longer purely academic. The Powley decision brings renewed prescience to Lamer C.J.'s statement in Delgamuukw: "Let's face it, we are all here to stay."211

Supra note 21.

For more detail on the nature and content of negotiations, see Bell, Settlement Legislation, supra note 21 at 7-20; and Bell \& MSAT, supra note 34 at 36-52.

Supra note 12 at 193.

Ibid.

Supra note 14 at 86. 